\title{
Executive Compensation and Corporate Governance in China
}

\author{
Martin J. Conyon \\ The Wharton School \\ Lerong $\mathrm{He}$ \\ SUNY Brockport \\ February 2011
}

\begin{abstract}
We investigate executive compensation and corporate governance in China's publicly traded firms. We also compare executive pay in China to the USA. Consistent with agency theory, we find that executive compensation is positively correlated to firm performance. The study shows that executive pay and CEO incentives are lower in State controlled firms and firms with concentrated ownership structures. Boardroom governance is important. We find that firms with more independent directors on the board have a higher pay-for-performance link. Non-State (private) controlled firms and firms with more independent directors on the board are more likely to replace the CEO for poor performance. Finally, we document that US executive pay (salary and bonus) is about seventeen times higher than in China. Significant differences in USChina pay persist even after controlling for economic and governance factors.
\end{abstract}

Keywords: China, Executive Compensation, Equity Incentives; China and the USA JEL classification: G3

Contact authors: Martin Conyon, email martin.conyon@gmail.com and Lerong He, email 1he@brockport.edu

Acknowledgements: We would like to thank an anonymous reviewer, Rocio Bonet, Peter Cappelli, Ingolf Dittmann, Mahmoud Ezzamel, William Forbes, Marc Goergen, Simon Peck, Luc Renneboog, David Yermack and Tianyu Zhang for comments. We are grateful to participants at the 2010 Managerial Compensation conference at Cardiff University and William Forbes (our discussant). We also thank seminar participants at Singapore Management University, and the Academy of Management for suggestions. Financial support from the Center for Human Resources at the Wharton School is gratefully acknowledged. 


\section{Introduction}

China's developing economy is one of the most important in the world. Firms are transitioning from previous state owned enterprises (SOEs) to modern firms. As market reforms deepen in China it is important to investigate how firms provide incentives to their top executives. Would we expect executive compensation and corporate governance in a socialist country such as China to look like it does in the US? The surprising result of our study is that in some respects it does. We document that economic drivers of executive pay, such as firm size and performance, are important in China as they are in the US. We show too that corporate governance is evolving in China mimicking important features of boards in the US, such as the adoption of independent directors and compensation committees.

This study investigates the relation between executive pay and firm performance in China's publicly traded firms from 2001 to 2005. By investigating the pay-for-performance relation we provide valuable information for assessing current and future market reforms. We use two data sets that cover all firms listed on China's domestic stock exchanges, the Shanghai and Shenzhen Stock Exchange. ${ }^{1}$ The institutional context in China is very important. First, the ownership structure of China's publicly traded firms is very distinct. Share ownership is often in the hands of the State, although (as we show) private control of firms is becoming more common. In addition, ownership is highly concentrated, especially by Anglo-Saxon standards. Publicly traded firms often have a single dominant shareholder. This raises important questions as to how effective market reforms might be, and whether appropriate

\footnotetext{
${ }^{1}$ The number of firms listed on the two major exchanges of China's Shanghai and Shenzhen stock exchanges has increased from 57 in 1992 to 1434 in December 2006 with a total market capitalization of 89,403 billion RMB (or about US\$11,462 billion). The size of China's stock market in August 2007 had a total market capitalization of approximately 245,300 billion RMB, surpassing the size of Japanese stock market.
} 
incentives are provided to senior managers. Also, the different types of ownership may imply that there are different objectives for the firm. The State control of firms may insulate inefficient managers or fail to provide appropriate financial incentives. We investigate the effect of State control on the setting of executive pay in China's listed companies. Specifically, we examine whether the link between pay and firm performance is stronger in privately controlled (i.e. non-State controlled) firms.

A second institutional feature we explore is the role of the board of directors, especially the effect of independent directors. China's listed firms have two-tier boards: a main board of directors and a supervisory board. Traditionally executives are often state-appointed bureaucrats whose effectiveness in delivering shareholder value has been questioned (Fan, Wong, and Zhang 2007, Xi, 2006). Since the early 2000s China's public firms have been under pressure from investors to reform (Allen, Qian, and Qian 2005; Jingu 2007). Increasingly, China has adopted Anglo-Saxon style corporate governance reforms, especially in relation to the board of directors. A salient example of this is the Code of Corporate Governance issued by the China Securities Regulatory Commission (2002). This code required firms to adopt best practice corporate governance structures, including adding independent directors to the board of directors, and separating the posts of CEO and chairperson. If these pressures reflect a tendency for increased quality of corporate governance then we would expect to observe different patterns of executive compensation and incentives. We examine whether the link between pay and firm performance is stronger in firms that have a greater proportion of independent directors on the board.

We make several significant contributions to the existing literature. First, we provide empirical evidence on the relation between CEO pay and firm performance from 2001 to 2005 . This is the ultimate goal of the study. We estimate executive pay 
equations that control for ownership structure, boardroom governance and the quality of management via firm fixed effects. We also estimate the elasticity of pay to performance by regressing the change in CEO pay on the change in shareholder value of the firm (Murphy, 1985). Overall, our study finds a positive and significant link between executive pay and firm performance. The empirical evidence also suggests that the pay-for-performance relation is stronger in non-State controlled firms and in firms with a greater proportion of independent directors on the board. The results attest to the importance of China's recent corporate governance and market reforms.

Second, we estimate the relation between the value of CEO shareholdings and firm performance. Previous executive pay studies using Chinese data have focused exclusively on cash compensation rather than CEO share ownership. However, studies using Western data document that incentives from equity ownership are very important, especially compared to cash compensation (Core and Guay, 1999; Hall, and Liebman 1998; Core et al. 2003; Conyon, and Murphy 2000; Murphy 1999). We show that the value of CEO share ownership is indeed important in China. The estimated value of the CEOs share ownership is significantly greater than cash compensation. The ownership of shares provides an important mechanism to align interests of CEOs and owners, as well as to focus CEO effort on value creation. In short, it is another way to measure the CEO pay-for-performance link.

Third, we investigate the relation between CEO turnover and firm performance as a complementary discipline mechanism to compensation incentives. Overall, we find that CEOs are replaced for poor stock performance. There is also a negative correlation between CEO turnover and accounting measures of firm performance. Corporate governance contingencies are important. We find little evidence of a significant statistical relation between CEO turnover and stock market 
performance in State controlled firms. In contrast, CEOs of privately controlled firms are statistically more likely to be replaced for poor stock price performance. We also find that CEOs are more likely to be replaced for poor stock market performance in firms if they have a higher proportion of independent directors on the board. Again, the results demonstrate the importance of China's corporate governance reforms.

Finally, we compare executive compensation in China to the United States. This unique aspect of our analysis adds to a growing literature on international executive compensation. We find that American executives earn about seventeen times more than their Chinese counterparts, although the effect is reduced after controlling for economic and governance factors. The econometric results show that many of the same variables determine pay in each country, particularly firm size, performance, and boardroom governance.

The remainder of the paper is organized as follows. Section two provides a brief explanation of the institutional context and hypothesis motivation. Section three explains the data and outlines the empirical models. Section four contains the main empirical results on the determinants of executive pay in China. Section five contrasts executive pay in China to pay in the US. Section six provides a conclusion.

\section{Institutional context and motivation}

Comparatively little is known about executive compensation and CEO equity incentives in China, especially relative to Anglo-Saxon economies (Kato and Long, 2006b). ${ }^{2}$ We investigate the determinants of executive pay in China's listed firms from 2001 to 2005. Our study makes an important distinction between cash compensation pay and incentives arising from the CEOs ownership of shares. Cash

\footnotetext{
${ }^{2}$ Our study investigates the determinants of executive pay and equity ownership in China's domestically listed firms, and the performance of their A shares. Other studies consider the determinants and consequences of executive pay in Hong Kong's Red Chip firms (Chen, Guan, and Ke, 2010; Ke et al., 2009; Magnan and Li, 2008).
} 
compensation measures the flow of pay received by an executive per time period. In contrast, the stock of CEO share ownership provides direct financial incentives to increase shareholder value (Conyon and Murphy, 2000; Murphy 1999; Core et al. 2003). In addition, we argue that it is important to control for firm and managerial quality via firm fixed effects in the pay regressions. In the following section, we consider briefly the institutional context and how it affects our empirical executive compensation models.

\section{Executive compensation in China}

We investigate executive pay in China. The standard economic theory of executive compensation is the principal-agent model (Holmstrom 1979; Mirrlees 1997, 1976; Murphy 1999). It predicts that firms design efficient compensation packages to solve moral hazards and motivate CEOs. ${ }^{3}$ The theoretical model posits a risk-neutral principal who designs an optimal contract for a risk and effort-averse agent in the presence of a moral hazard problem. Boards set CEO pay and incentives based on economic factors, the magnitude of agency problems, and monitoring difficulty in order to align shareholder and managerial interests (Core et al. 2003; Core, and Guay 1999; Fama, and Jensen 1983b; Jensen, and Meckling 1976). ${ }^{4}$ Agency theory predicts that executive pay is positively correlated to firm performance. It is, however, relatively silent on the functional form of the estimating equation (e.g. whether to use current or lagged performance measures) and other types of variables to be included. Holmstrom's (1979) "informativeness" principle predicts that any variable that is

\footnotetext{
${ }^{3}$ Murphy (1999) provides an authoritative review of the economic determinants of CEO pay and empirical evidence amassed for the US economy.

${ }^{4}$ The contract approach is standard in the accounting, finance and economics literature. Core, Guay, and Larcker (2003) define an efficient (or optimal) contract as one that: "that maximizes the net expected economic value to shareholders after transaction costs (such as contracting costs) and payments to employees. An equivalent way of saying this is that ... contracts minimize agency costs."
} 
informative about CEO effort can be contracted upon. In our empirical work we control for a set of economic and corporate governance variables that have been shown to be important in previous research (Core et. al., 1999).

Compensation disclosure is different in China compared to the US. Chinese Security Law (1999) requires that listed firms disclose information about management shareholdings. The Chinese Securities Regulation Committee (CSRC) regulates the disclosure of executive compensation information. Early regulation did not require listed firms to disclose complete executive compensation information in their annual reports (CSRC, 1998). Since 2001 publicly traded firms are required to report the sum of total compensation for the three highest-paid management and the three highestpaid board members (including executive board members). Compensation disclosure was not required for each individual separately from 2001 to 2005 , which is the time period of our study (CSRC, 2000, 2002).

However, there have been further changes in disclosure rules. From 2006 onward publicly traded firms are required to report each individual board member and top management's total compensation as the sum of salary, bonus, stipends, and other benefits (CSRC, 2005, 2007). In addition, firms are also required to disclose information on stock options, including total exercisable shares, exercised shares, exercising price, market price at the reporting time. ${ }^{5}$

Existing China pay studies have shown a positive correlation between pay and performance. Early research by Mengistae and Xu (2004) examined CEO pay in

\footnotetext{
${ }^{5}$ In 2005, the CSRC launched a structural reform program aimed at eliminating non-tradable shares. The reform required listed companies to transfer non-tradable shares to tradable shares by compensating existing shareholders in various ways by offering bonus shares, cash and stock options. This reform was accompanied by a series of changes in the Corporate Law and Security Law, which also paved the way for granting stock options to executives. Effective from 2006, the new rule allow publicly traded firms that have successfully completed structural reforms to offer stock options or restricted stocks to their higher management, board and supervisory board members, excluding independent board members, CSRC (2005).
} 
approximately 400 Chinese state-owned enterprises in the 1980s using survey data. They find the CEO pay sensitivity decreases with the variance of performance. More recently, Kato and Long (2006b) investigated a sample of 937 publicly traded firms in China from 1998 to 2002 . They find that executive cash compensation is positively related to firm performance. They also find some evidence that the pay-forperformance link is weaker in State owned firms. Firth, Fung and Rui $(2007,2006)$ examined a sample of 549 listed firms in China from 1998 to 2000. They too find that cash compensation is related to firm performance and that China's distinct ownership affects the level of cash pay. We build on these by investigating a later period when market reforms have deepened, and use a much larger set of approximately 1300 firms from 2001 to 2005 . Chen et al (2010a) also demonstrate a positive correlation of pay to performance. Our study is appreciably different from theirs. We investigate the pay-for-performance relation controlling for management quality via firm fixedeffects, the role of ownership structure, and the effect of independent directors on the main board. In addition, and in contrast to all previous studies, we compare executive compensation in China to the US.

\section{Ownership of publicly traded firms in China}

We argue that China's distinct pattern of ownership and control has implications for the determination of executive pay. There are three major classes of share ownership. First, the State owns shares, held through government agencies. Second, legal entities can own shares, held through state controlled legal persons, or privately controlled legal persons. Finally, individuals, institutions, and private businesses can own shares privately. When a State-owned-enterprise (SOE) is listed, only a small proportion of equity is sold to private investors in the IPO process. The state and parent SOEs still retain sufficient shares in the form of state shares or legal 
person shares to retain voting control, which typically accounts for two thirds of total shares outstanding (Qian, 1995). State shares and legal entity shares are (generally) non-tradable. There are circumstances when they can be exchanged, but the process is complex (Xu, 2004). A reform was undergoing to make all shares tradable starting from 2005. In addition, a Chinese company may also issue three types of tradable shares. Tradable "A" shares are listed on the two domestic exchanges (Shanghai and Shenzhen) to domestic investors and denominated in Renminbi (RMB). "B" shares are issued to foreign investors traded in either US dollar or Hong Kong dollar. Finally, a Chinese firm may also trade on the Hong Kong Stock Exchange and issue so called " $\mathrm{H}$ " share. Our study deals with performance arising from the "A" shares traded in domestic stock exchanges.

The ownership of China's publicly traded firms is highly concentrated. In most firms there is a single dominant shareholder whose large share ownership gives considerable power and influence over the way the firm is run. This is especially the case regarding the appointment and compensation of the CEO or the board. Typically, the largest shareholder owns about $43 \%$ of the firm's shares, the second largest about $9 \%$, and the third largest about 4\% (see Section 4 below). Our figures are consistent with those produced by $\mathrm{Xu}(2004) .{ }^{6}$ China's ownership pattern stands in stark contrast to the US, where low-concentration and ownership diffusion is the norm. It is rare for investors to own more than $10 \%$ of common equity in Anglo-Saxon firms.

Ownership concentration has important consequences for the pattern of executive compensation and CEO equity incentives (Core et al., 1999). Agency theory predicts that when ownership is dispersed, individual owners have weak incentives to invest in monitoring and to exert influence over key corporate decisions

\footnotetext{
${ }^{6} \mathrm{Xu}$ (2004) finds the largest shareholder percentage is $46.23 \%$, the second largest is $6.96 \%$ and the third largest is $2.85 \%$. This is based on a study of Chinese firm ownership from 1996 to 2001 .
} 
(Fama, and Jensen 1983a; Jensen et al. 1976). This free-rider problem may be mitigated by concentrated share ownership. A high equity stake in the company provides block-holders and controlling shareholders with strong incentives to supervise managerial activities (Jensen, and Warner 1988). As a result, concentrated ownership often indicates that shareholders are able to better guard their interests in their firms. Core, Guay and Larcker (2003) and Shivdasani (1993) thus hypothesize that large share stakes by outside shareholders will also mitigate potential CEO entrenchment and is predicted to be negatively correlated with CEO compensation. Also, more concentrated ownership may suggest the optimal contract contains fewer financial incentives to motivate the CEO, especially if monitoring and equity incentives are substitutes. This suggests that CEO equity incentives are a decreasing function of ownership concentration. Set against the beneficial effects of concentrated ownership are the costs associated with entrenchment and private benefits of control of a single large shareholder. Large shareholders may expropriate minority shareholders, or promote their own objectives over those of other shareholders. This may occur via tunneling or other rent extraction strategies (La Porta et al. 1998, 2000). The problem of expropriation by controlling shareholders is extremely severe in Chinese stock markets because of a more primitive disclosure system and weak corporate governance mechanisms (Ding et al., 2007).

The type of ownership is also important. When the State is the firm's ultimate owner the CEO is more likely to be a bureaucrat (Firth et. al. 2007) and managerial quality may be lower. Instead, managerial quality may be higher in privately controlled firms. This increased demand for managerial talent suggests that equilibrium wages will be lower in state controlled firms. In addition, private ownership is likely to result in compensation contracts that focus managerial behavior 
on maximizing firm value. Conversely, state controlled firms might pursue political or multiple objectives, such as employment growth, rather than profit maximization. Privately owned firms, therefore, are expected to set optimal contracts with greater pay-for-performance incentives. To summarize, we expect the type of firm ownership to impact the level of executive compensation, pay-for-performance and the provision of equity incentives in China's publicly traded firms.

\section{Boards of directors in China's publicly traded firms}

As noted in the introduction, China operates a two-tier board system consisting of a main board of directors and a supervisory board. Traditionally, the state has huge influence on the appointment of board and supervisory board members. An enduring concern is that state-appointed bureaucrats are ineffective in monitoring management (Fan, Wong, and Zhang 2007, Hu et al, 2010). In response to shareholder pressure, and deepening market reforms, China's listed firms have increasingly adopted Anglo-Saxon style internal corporate governance structures (Allen, Qian, and Qian 2005; Jingu 2007; and Chen et al 2010a). An important example of this is the Code of Corporate Governance issued by the China Securities Regulatory Commission (2002). This code required firms to add independent directors to the main board of directors and separate the posts of CEO and chairperson. The expectation is that one-third of the board should comprise independent directors. The corporate governance code defines director independence as: "The independent director shall be independent from the listed company that employs them and the company's major shareholders." ${ }^{, 7}$ Unlike earlier studies we focus on this precise definition of independence, not just non-executive directors. If these pressures reflect a tendency for increased quality of corporate governance then

\footnotetext{
${ }^{7}$ A non-executive director may be independent, but not necessarily so. A non-executive does not hold a position in the listed firm but they may hold a position in the parent company or major shareholder of the firm.
} 
we would expect to observe different patterns of executive compensation and incentives. In short, we expect the pay-for-performance link to be stronger in firms that have a greater proportion of independent directors on the board.

In line with extant research, we assert that board structure will influence executive pay in China (Conyon, and Peck 1998; Core et al. 1999). It is frequently argued that the board of directors should consist of independent outside directors (Core et al. 1999, Hermalin and Weisbach, 2003). ${ }^{8}$ One reason for this is that inside directors are more loyal to the CEO or the CEO can exert power and influence over them by controlling factors such as their career opportunities. Outside directors, on the other hand, have incentives to effectively monitor the CEO because they are subject to less CEO influence and have reputations to protect in the labor market (Fama and Jensen, 1983b). We expect, more independent directors on the board are associated with less managerial opportunism and more efficient contracts. ${ }^{9}$ In addition, previous research argues that board effectiveness is influenced by the size of the board. Jensen (1993) argues that large boards are less effective than small boards, because they may suffer from free-riding problems in decision-making and control thereby diluting monitoring capabilities (see also Yermack 1996). Similarly boards that combine the posts of CEO and chairperson vest more power with the CEO, and may suffer greater agency costs (Jensen, 1993). Lastly, firms without compensation

\footnotetext{
${ }^{8}$ As in the USA and Anglo-Saxon firms, the nominating committee is an important mechanism by which directors get first nominated and then selected. We found that nomination committees are becoming an increasingly important phenomenon in China, since the governance reforms of 2002. The percentage of firms with nominating committees was only $4 \%$ in 2001 ; but in 2002 it was $21 \%, 30 \%$ in $2003,34 \%$ in 2004, and 37\% in 2005. It appears that China's listed firms are using the institution of nomination committees in order to help select and add members to the board of directors.

${ }^{9}$ Although majority voting is one way for independent directors to assert their influence, in practice they may be constrained. We suspect that power and political dynamics can have an important influence on board decisions and how the CEO, independent directors, State or other representatives interact. These board process issues are difficult to quantify and, unfortunately, we do not have variables to measure this. In addition, the State can be very powerful. The proportion of independent directors on the board is about one-third, so the non-independent State influenced directors can still have significant power and influence.
} 
committees may be less effective at setting executive pay (Newman and Mozes, 1999; Conyon and Peck, 1998). In summary, our pay regressions include measures of independent directors, board size, combined CEO and chair position, and the presence of a compensation committee.

\section{Methods}

\section{Data}

Our study uses data on publically traded Chinese firms listed on the domestic exchanges from 2001 to 2005 . We combined two separate data sets. First, the executive compensation and corporate governance data were supplied by the China Center for Economic Research Sinofin Information Service (CCER/SinoFin). Second, the financial performance and accounting data are from the CSMAR-A financial database. Together these two data sets account for almost all firms listed on the Shanghai and Shenzhen Stock Exchanges. The data sets have been used in previous research (Kato and Long 2006b). It is important to comment on the quality of the executive compensation and corporate governance data. The SinoFin data are collected directly from public firms' annual financial reports as published in Securities Time, Shanghai Securities Daily, China Securities Daily, and other major newspapers designated by the China Securities Regulatory Commission (CSRC). Different individuals manually enter the data twice. This ensures coding accuracy and the integrity of the data.

The following describes how we arrive at our final set of firms. The original combined data set (SinoFin and CSMAR-A) consisted of 1381 unique publicly traded firms on the two domestic Chinese exchanges for the years 2001 to 2005 . These firms account for approximately $98 \%$ of all listed firms. The near universal coverage of firms helps attenuate selection biases, which may have been a cause for concern in 
earlier studies. In order to estimate the statistical models we required non-missing data on executive compensation. This resulted in the deletion of only five firms. We also required non-missing data on ownership type (for example, State control), firm size, annual stock returns, return on assets, and boardroom variables such as the proportion of independent directors. Also, in our empirical work below we estimate panel data models using a first-difference strategy to eliminate firm fixed effects. This required the firms to have at least two consecutive years of data. Overall, the selection procedure resulted in a final sample of 1342 unique firms with 5928 firm-year observations. ${ }^{10}$ The panel data set has multiple time-series observations per firm (i.e. it is unbalanced) reflecting the fact that firms join or leave the stock exchanges. ${ }^{11}$

\section{Model estimation}

We estimate the following fixed-effects panel data model, controlling for firm size, ownership structure and boardroom governance:

$$
\ln (\mathrm{PAY})_{\mathrm{it}}=\alpha_{\mathrm{i}}+\beta_{1} \mathrm{SHR}_{\mathrm{it}}+\beta_{2} \mathrm{ROA}_{\mathrm{it}}+\beta_{3} \ln (\mathrm{SALES})_{\mathrm{it}}+\beta_{4} \mathrm{X}_{\mathrm{it}}+\varepsilon_{\mathrm{it}}
$$

The term $\ln (\mathrm{PAY})_{\mathrm{it}}$ is the logarithm of executive cash compensation in firm $i$ at time $t$. Executive compensation is the aggregated pay of the top three officers, defined as the sum of basic salary, bonus, stipends, and other benefits. We divide the single aggregated pay figure by three to get an estimate of the average executive's pay. ${ }^{12}$

\footnotetext{
${ }^{10}$ It is comforting that the selection procedure led to a loss of only 39 firms from the initial sample of 1381 companies. We managed to keep about $97 \%$ of our original set of firms.

${ }^{11}$ The balance of the panel is as follows. There are 119 firms with 2 years of data (238 observations), 96 firms with 3 years of data (288 firm-year observations), 233 firms with 4 years of data (932 firmyear observations), and 894 firms with 5 years of data (4,470 firm-year observations). The number of unique firms is therefore $1342(=119+96+233+894)$ and the total number of firm-year observations is 5928. The unbalanced panel is not an issue for estimation purposes, and the broad results reported below hold for the balanced data set also.

${ }^{12}$ As noted earlier, the CSRC has approved revised executive compensation disclosure rules. From 2006 onwards the total pay of each three highest-paid individuals will be disclosed separately.
} 
The use of cash compensation is consistent with previous research (Firth et al. 2007; Kato et al. 2006b; Chen et al. 2010a).

The main independent variables of interest are the performance of the firms. These are defined in two ways. First, we use a market-based measure (Murphy, 1999). This is the annualized stock return over the twelve months (SHR). An accountingbased measure of performance is also included in the model (Core et al 1999). This is measured as return on assets, defined as net profits divided by the book value of assets (ROA). We predict these variables are positive (i.e. $\beta_{1}$ and $\beta_{2}>0$ ).

An important feature of our research design is the use of fixed-effects panel data methods to control for heterogeneity in firm and managerial quality (Wooldridge, 2002). Cross-section regressions may omit significant explanatory variables, potentially causing statistical bias in the estimated pay-for-performance relation. For example, if managerial quality is correlated with firm performance and executive wages, then its omission from the pay regression may result in erroneous estimation of the pay-performance relation. Features such as managerial quality, corporate culture, or the quality of the firm are likely to be important factors in the China context, and are not usually measured in prior studies. In a recent paper, Graham, Li and Qiu (2010) report that firm fixed effects are an important determinant of executive compensation. In consequence our models control for firm fixed effects (the $\alpha_{i}$ terms in equation (1)). They filter out time-invariant factors that may contaminate the pay-for-performance estimates. ${ }^{13}$ We also present OLS and random effects results. The purpose of this is to illustrate the importance of controlling for the fixed effects.

\footnotetext{
13 Ideally we would want to control for managerial fixed effects too (see Graham et. al. 2010), but cannot do so because we do cannot isolate the identity of the CEO in our data. CEO fixed effects may control for the degree of risk aversion of managers (Conyon, Core and Guay, 2010). It may be especially important for those companies that issue equity to managers because these managers' wealth tends to be even more concentrated in the firm they manage therefore increasing their risk aversion and, potentially, increasing the conflicts with shareholders.
} 
The model includes a set of independent right hand side control variables, $\mathrm{X}$. Firm size is measured as the logarithm of firm sales, SALES; Growth opportunities are defined as the market value of the firm divided by the book value of assets, MKT_BK (Smith and Watts, 1992). Firm risk is measured as the log of the standard deviation of stock returns over the calendar year, VOL (Core et al, 1999). We also control for ownership structure. State control is an indicator variable set equal to one if the ultimate owner is the State, and zero otherwise, $\mathrm{STATE}^{14}$. We also control for ownership concentration. This is measured as the share ownership of the largest shareholder, LG1_OWN (Shivdasani, 1993). The boardroom governance variables are: The percentage of the board comprised of independent directors, IND_DIR (Hermalin and Weisbach, 1998, 2003). Board size is measured as the number of individuals on the main board, BOARD_SIZE (Yermack, 1996). The leadership structure of the firm is a dummy variable set equal to one if the posts of CEO and chairman are combined, and zero otherwise, COMBINE (Brickley et. al, 1997). The presence of a compensation committee is a dummy variable equal to one if the firm has a compensation committee and zero otherwise, COMP_COMM (Newman and Mozes, 1999). The boardroom governance variables are sourced from the SinoFin dataset. Finally, regression models contain a set of industry dummy variables ${ }^{15}$ to capture industry variation in managerial talent and a set of time dummies to capture year effects and macro-economic shocks. The term $\varepsilon_{\text {it }}$ is the equation error.

\footnotetext{
${ }^{14}$ This variable is provided by SinoFin, who identifies the type of the ultimate owner of the firm.

15 CSRC classifies industries to 13 categories: A: Agriculture and fishery, B: Mining, C: Manufacturing; D: Electricity, water and other energy manufacturing and supply; E: Construction; F: Transportation and logistics; G: Information technology; H: Wholesales and retails; I: Finance and insurance; J: Real estate; K: Service; L: Communication; M: Others. Firms sometimes report different industry classification in different years. When this occurs, the most recent year industry code is applied.
} 
Cash compensation provides only one source of incentives for CEOs. Another mechanism is the incentives arising from the CEOs' ownership of firm stock. We therefore estimate a CEO share ownership model. This model is the same as the cash compensation model in equation (1) above, except that we replace the dependent variable with the value of CEO shareholdings. Specifically, CEO_OWN is the natural logarithm of the value of CEO shareholdings. We measure incentives from share ownership as the dollar change in the value of the CEO's stock wealth arising from a one percent change in the stock price. ${ }^{16}$ In our context it can be written as: $1 \% \times$ (share price) $\times($ the number of shares held). Stock ownership directly links CEO wealth to shareholder value and is a major component of total CEO incentives in U.S. firms (Conyon and Murphy 2000; Jensen and Murphy 1990; Hall and Liebman 1998). In China, during the time period of our study the aggregate number of options held is zero, so equity incentives are derived wholly from share ownership. ${ }^{17}$

In addition, we perform a regression of the change in the logarithm of executive pay on the change in shareholder wealth. This is the elasticity approach to estimating the pay-for-performance relation (Coughlan and Schmidt, 1985, Murphy, 1986). The baseline model is:

$$
\Delta \ln (\text { Pay })_{\mathrm{it}}=\beta_{0}+\beta_{1} \Delta \ln (\mathrm{SW})_{\mathrm{it}}+\beta_{2} \Delta \mathrm{ROA}_{\mathrm{it}}+\beta_{3} \Delta \ln (\mathrm{SALES})_{\mathrm{it}}+\beta_{4} \Delta \mathrm{X}_{\mathrm{it}}+\varepsilon_{\mathrm{it}}(2)
$$

where $\Delta \ln (\mathrm{SW})$ is the change in shareholder wealth between $\mathrm{t}-1$ and $\mathrm{t}$, and is equal to the continuously accrued rate of return on common stock. The term $\Delta$ is a difference operator: $\Delta X_{i t}=X_{i t}-X_{i, t-1}$. The estimated coefficient $\beta_{1}$ is the elasticity of cash compensation with respect to shareholder value. The first-difference equation

\footnotetext{
${ }^{16}$ Core et al. (2003) and Baker and Hall (2004) provide a discussion of the role and types of equity incentives.

${ }^{17}$ If there were stock options the relevant measure is: $1 \% \times($ share price $) \times($ the number of shares held) $+1 \% \times($ share price $) \times($ option delta $) \times($ the number of options held $)$. The options are weighted by the delta of the option, reflecting the likelihood that the option will end up in the money.
} 
implicitly eliminates time-invariant firm fixed effects. We also estimate equation (2) separately for State and non-State controlled firms and for firms with a high percentage of outside directors on the board (IND_DIR $>=25 \%$ ), and those firms that do not (IND_DIR $<25 \%$ ). The estimation allows the coefficient estimates on all of the variables to have a different effect in the separate conditions. ${ }^{18}$

\section{Empirical results for China}

\section{Descriptive results}

Table 1 presents descriptive statistics on executive compensation for China's listed firms by year (Panel A) and broad industrial sector (Panel B). Panel A shows average (median) executive compensation over the 2001-2005 sample period is about 152,000 $(107,000)$ renminbi $(\mathrm{RMB})$. Using the official 2005 exchange rate of 1 US $\$=8.20$ $\mathrm{RMB}$, average (median) executive compensation over the period is approximately $\$ 19,000(\$ 13,000)$ US dollars. However, if one uses the Penn World Table purchasing power parity (PPP) rate of about 2.2 in 2005 then the US dollar amount is about $\$ 69,000(\$ 49,000) .{ }^{19}$ Although China executive pay may seem low by US standards, it is high compared to the typical employee wage in China. Annual average employee income in 2005 was about $18,000 \mathrm{RMB}$, suggesting that the ratio of executive to employee pay was about eight. ${ }^{20}$

Table 1 also shows that executive pay grew from 2001 to 2005. Average executive compensation rose from about $105,000 \mathrm{RMB}$ in 2001 to approximately

\footnotetext{
${ }^{18}$ It is therefore equivalent to estimating a model with a full set of interaction terms on every independent and control variable.

${ }^{19}$ We discuss the issue of PPP rates in Section 5 below when contrasting China to the USA.

20 Annual employee pay (in RMB) was 10,870 in $2001 ; 12,422$ in $2002 ; 14,040$ in $2003 ; 16,024$ in 2004; and 18,415 in 2005. The source of the data is the China Statistical Yearbook.
} 
$196,000 \mathrm{RMB}$ in 2004 , and then fell to about 154,000 in $2005 .^{21}$ To estimate the rate of growth in executive pay we ran a regression of the logarithm of executive pay on a linear time trend. The results indicate that executive pay has grown by about $10.3 \%$ per year over the period 2001 to $2005(\beta=0.098, t=11.8)^{22}$. Finally, Panel B shows the distribution of compensation across broad industry groups. It is noteworthy that most of the firms are within the manufacturing sector.

Table 2 gives the average values of key variables used in the study. Panel A provides information on executive compensation, the value of CEO share ownership, and boardroom structures variables, such as the percentage of independent directors on the board. Executive compensation and the value of CEO share ownership are expressed in thousands of RMB. A key point is that the value of CEO share ownership is higher than the level of executive pay. Over the period from 2001 to 2005 the average value of cash compensation is about 151 thousand RMB. In contrast, the average value shareholding is approximately 2177 thousand RMB. The notional value of the stock of CEO shareholdings is about fourteen times the value of cash compensation. Since the value of CEO share ownership varies directly with asset prices, this provides an automatic mechanism to motivate CEOs to create firm value. The importance of equity ownership (compensation) has not been highlighted in previous studies of compensation in China.

The corporate governance of China's listed firms has changed from 2001 to 2005. In terms of boardroom structure, we find an increased adoption of Western style governance practices. The percentage of independent members on the board has

\footnotetext{
${ }^{21}$ The full explanation for the decline in 2005 is unclear. One reason may be declining firm performance between 2004 and 2005, since return to shareholders and return on assets also fell over this time period.

${ }^{22}$ Calculated as $\mathrm{e}^{0.098}-1$.
} 
increased from about $6 \%$ in 2001 to about $34 \%$ in $2005 .{ }^{23}$ The size of the main board of directors is about ten members and relatively constant over time. About $11 \%$ of firms combine the posts of CEO and chairperson over the sample period. Finally, the proportion of firms that have adopted a compensation committee for setting executive pay has increased from about $8 \%$ in 2001 to approximately $50 \%$ in 2005 . As noted, the raw data show significant changes in the internal control and governance of firms.

Table 2 Panel B provides further institutional context to our study. State ownership control has declined from 2001 to 2005 . The State was the ultimate owner in about $82 \%$ of firms in 2001 and only $71 \%$ in 2005 . In contrast, private ownership and control has more than doubled over the same short period. About $27 \%$ of firms were privately controlled in 2005 compared to $11 \%$ in 2001 . The State's ownership control of firms has diminished, as market reforms deepened. The ownership of publicly traded firms is highly concentrated in China. For expositional purposes we present the ownership stakes of the largest three shareholders separately. The largest shareholder owns about $43 \%$ of the firms shares, the next largest about $9 \%$ and the third largest about 4\%. The situation contrasts markedly to Anglo-Saxon economies. Table 3 provides the sample means and a correlation matrix of the variables used in the regression analysis. We note that the average stock market and accounting performance of these firms is quite poor. This is consistent with Firth et al (2007) who remarked on the "lamentable" performance of listed firms.

\section{Econometric results}

Table 4 documents the relation between executive compensation, firm performance, ownership and control. Columns (2) and (3) are the random and fixed effects

\footnotetext{
${ }^{23}$ The significant increase of independent directors on the board is due to the regulation issued by CSRC in August 2001, “Guides to the Establishment of Independent Directors System”, which mandate at least one third of the board members in listed firms should be independent directors.
} 
estimates using current dated measures of firm performance. Columns (4) and (5) use lagged performance measures. ${ }^{24}$

The cross-section results show that executive pay is positively correlated to firm performance. Both the shareholder returns and return on assets variables are significant after controlling for firm size, growth opportunities, and boardroom variables such as the fraction of independent directors. The models also control for macroeconomic effects via the time dummies and cross industry differences in the demand for executive talent. This evidence is consistent with the board of directors providing managers with incentives through cash compensation contracts in Chinese publicly traded firms. The results are in agreement with OLS results from prior research (Firth et al. 2007; Mengistae et al. 2004; Kato et al. 2006b). There is a positive and significant association between executive pay and firm size. The coefficient is an elasticity estimate and shows a $10 \%$ increase in firm revenues is associated with a $2 \%$ increase in pay. It is consistent with prior Anglo-Saxon research. Murphy's (1999) review suggests the CEO compensation-size elasticity is typically in the range of 0.20 to 0.45 . The cross-section results also show that pay is positively related to firm growth opportunities, the percentage of directors on the board and the presence of a compensation committee. It is negatively related to firm risk, State control of firms and concentrated share ownership.

A concern with the cross section data is omitted variable bias, so we next estimated both random and fixed effects models. ${ }^{25}$ Using current dated performance we find that executive pay is related to return on assets, but not stockholder returns. However, when we used lagged performance variables we find that executive pay is

\footnotetext{
${ }^{24}$ We lagged only the performance terms since this is the variable of interest. The performance results are qualitatively unaltered when we lagged all the right hand side variables in columns 4 and 5 .

${ }^{25}$ The random effects allow the errors to be correlated over time, but do not account directly for firm specific (time-invariant) factors.
} 
statistically related to stock returns, but not return on assets in the fixed effects equation. The functional form of the estimating equation appears to be important in isolating the pay-performance relation. Broadly speaking, there is a correlation between pay and performance.

As previously discussed, if unobservable firm heterogeneity is correlated with the observable variables then the estimating equation could be misspecified leading to omitted-variable bias. It is therefore important to control for such unobserved firm heterogeneities. To investigate further, we compared the OLS and random effects estimates with those of a fixed effects model. We find the signs of the coefficients are similar across the models but some variables loose significance and the estimated magnitude of the coefficients is sensitive to the estimation method. We find that the magnitude of the coefficient estimates declines as one moves from the OLS to the random effects to the fixed effects specification. We performed a Hausman test to compare the OLS and random effects models to the fixed effects specification. The tests rejected the hypothesis that fixed effects are uncorrelated with the observable determinants. Also, we could not reject the hypothesis that the OLS and random effects estimates are inconsistent at the $1 \%$ level. Therefore, the fixed effects models are the appropriate specification. ${ }^{26}$

Table 5 shows the relation between CEO share ownership, firm performance, ownership and control. Column (1) is the pooled sample estimated using OLS methods. Columns (2) and (3) are panel data random and fixed effects estimates using

\footnotetext{
${ }^{26}$ We also experimented with additional control variables to see if foreign ownership had an effect on compensation practices. We defined a dummy variable equal to one if the firm issued any $\mathrm{B}$ or $\mathrm{H}$ shares $($ mean $=0.075)$. It was significantly positive in the cross section regression, but insignificant in the preferred fixed-effects regression. We also defined a dummy variable equal to one if the ultimate owner was foreign (mean $=0.01$ ). This variable was generally positive and significant, but the number of observations that are ultimately foreign owned is very small $(=35)$ and represented only 8 unique firms in our data. See also Chen, Liu and Li (2010).
} 
current dated measures of firm performance. Columns (4) and (5) use lagged performance measures. We find a positive cross section correlation between CEO share ownership incentives, stock market performance and return on assets. Better performing firms provide their CEOs with greater share incentives. We also find that CEO equity incentives and growth opportunities are positively correlated. We find CEO share ownership is negatively associated with ownership concentration of the largest shareholder. This is consistent with greater monitoring, and supports the hypothesis that owners use monitoring and incentives as substitute mechanisms to achieve optimal corporate governance goals. We also find that ownership type matters. CEO share ownership incentives are lower when the State is the ultimate owner of the firm. This is consistent with privately controlled firms providing CEOs with more share incentives to promote value creation. In general, the boardroom governance variables are not significant. Overall, the pattern of cross-sectional evidence is consistent with the hypothesis that Chinese firms attempt to set incentive contracts optimally to mitigate agency costs. ${ }^{27}$

As with the pay equations we estimate random and fixed effects model, using both current and lagged performance. Using current performance measures we find that few variables are significant in the random or fixed effects specification. This may not be surprising if the covariates are acting as proxies for omitted variables, or if the included variables change slowly over time. Using lagged performance we find that firms with higher performance and higher firm revenues have higher CEO share

\footnotetext{
${ }^{27}$ We investigated the cross section data further. In un-tabulated results we found that in State controlled firms CEO share ownership is more likely to be correlated to accounting performance rather than stock market performance. In contrast in privately controlled non-State firms CEO equity incentives are strongly related to both stock market and accounting performance. Firm performance appears to be more important driver of CEO incentives in privately controlled firms. We also found that firms with a higher percentage of independent directors on the main board are more likely to link CEO equity incentives to firm performance.
} 
ownership. This is consistent with firms contracting to reduce agency costs and motivate CEOs. The Hausman tests did not reject the hypothesis that the random effects estimates are inconsistent at the $1 \%$ level, and so the fixed effects model is preferred. As noted the lack of significance of some of the covariates is not unforeseen in the fixed effects specification. For example, State control has an important "fixed" component to it because firms do not frequently change ownership control and there is little within firm variation in the variable. ${ }^{28}$

\section{Pay-for-performance sensitivities}

Table 6 provides further evidence on the pay-for-performance relation by using the elasticities approach. We find a positive correlation between the change in CEO pay and the change in shareholder wealth, and the growth in accounting returns. The other variables in the equation are largely insignificant. As before, this may be expected if the variables change only slowly over time. However, there are two interesting exceptions. We find that firms that switch from being State controlled to non-State controlled have lower conditional levels of pay growth. Also we find that firms that adopted a compensation committee have higher rates of pay growth.

We next split the sample into State and non-State firms. We find the growth in CEO pay is positively correlated to the growth in shareholder wealth in both the State and non-State firms. The association between pay growth and the change in accounting returns is not significant. In non-tabulated results we found that there were some interesting differences in the cross-section data, specifically the correlation between pay and performance was stronger in non-State privately controlled firms.

\footnotetext{
${ }^{28}$ Importantly, not all firms provide equity to the CEOs (about $32 \%$ of firms provide equity and $68 \%$ do not). Firms that provide CEO equity have larger sales, better stock returns, less stock volatility, and have lower ownership concentration. These findings are based on probit regressions (where $1=\mathrm{CEO}$ receives equity; $0=\mathrm{CEO}$ does not receive equity). We also conducted a sensitivity analysis of the results in Table 5 and estimated the CEO share ownership equations using Tobit methods, taking into account the zero lower bound. The qualitative results we discussed in Table 5 are unaltered.
} 
Table 6 also investigates the effect of independent directors on the pay-forperformance relation (columns 4 and 5). There is a positive correlation between executive pay and shareholder returns in firms when there is a higher fraction of independent directors on the board. However, there is no correlation between pay and stock returns in firms with a low fraction of independent directors. This suggests that greater monitoring quality by the board is associated with a stronger link between pay and market performance. In this respect, the boardroom reforms of the early 2000s in China are to be welcomed, as it is associated with greater pay-for-performance. We also find that there is a positive correlation between executive pay and return on assets in firms with a low percentage of independent directors on the board. Overall, these fixed effects (elasticity) estimates demonstrate that there is, in general, a positive correlation between executive pay growth and the change in shareholder wealth. Also, there is some evidence that a higher fraction of independent directors on the main board makes the pay-performance link stronger.

\section{CEO turnover and firm performance in China}

The possibility of job termination for poor performance may provide additional incentives for CEOs to promote owner interests, beyond the alignment effects provided by compensation and firm equity (Murphy, 1999, Conyon, 1998). Indeed, one might conjecture that compensation and other job benefits are substitutes. For example, CEO pay may be low in China because tenure is long, or non-pecuniary benefits are abundant. In addition, politically connected CEOs may be insulted from the consequences of poor performance. As a result, CEO termination (especially in case of poor performance) may be rare. We therefore test whether poor performance is correlated with CEO replacements in our data set to rule out this alternative explanation for the observed pattern of CEO compensation. 
Following extant research we ran a probit regression of CEO turnover on firm performance (Murphy, 1999, Weisbach, 1988). The dependent variable is the change in CEO (CEO_CH), and is a binary variable equal to one if the firm replaces the CEO in a given year, and zero otherwise. In the data, approximately one third of Chinese firms replace their CEO in a given year (mean=0.33). This is higher than the CEO turnover reported in US studies. Kaplan and Minton (2006) report a turnover rate of about $17 \%$.

Table 7, column 1, reports the marginal effects from running a probit regression. We find that poorly performing firms are more likely to replace their CEOs. The evidence shows that market based (SHR) and accounting measures (ROA) are negatively correlated to CEO turnover, but only stock returns are significant. We conclude, that CEOs in China are disciplined for poor firm performance. Our results are broadly consistent with earlier studies (Kato and Long, 2006a, 2006c).

In addition, we investigate the effect of State control and the role of independent directors on the likelihood that CEOs are replaced for poor performance. Table 7 (column 2) shows an insignificant relation of CEO turnover to stock returns in State controlled firms: poor stock returns are not associated with CEO replacement. However, CEOs are replaced for poor accounting performance. The reverse is true in privately controlled non-State firms (column 3). CEOs of firms with poor stock returns are disciplined with a higher probability of dismissal. However, there is no statistical link to accounting performance. It appears that privately controlled (nonState) are more likely to use market based performance measures to discipline managers.

There is also evidence that independent directors perform a useful monitoring function. Table 7 (column 4) shows that boards with a higher fraction of independent 
directors on the board are more likely to replace the CEO for poor performance. On the other hand, we find no relation between CEO turnover and firm performance in firms with a low percentage of independent directors on the board (column 5). This is supportive evidence of the usefulness of the institutional and governance reforms of the 2000s requiring increased board independence.

\section{Comparing executive pay in China to the USA}

In this section we provide the first evidence on pay differences between China and the US, adding to the growing literature on international executive pay. Murphy and Sandino (2010) compare the United States with Canada focusing on the role of compensation consultants. Conyon and Murphy (2000) compare the US to the UK, and Conyon, Core and Guay (2010) and Conyon, Fernandes, Ferreira, Matos, and Murphy (2010) compare the United States to European economies. The general idea in such studies is that in efficient labor markets, with few transaction costs, competition should lead to factor price equalization. In consequence, similar skilladjusted compensation should be observed across countries. Empirically, however, studies often document pronounced CEO pay differences across countries.

Clearly, the United States and China are starkly different both politically and in terms of governance arrangements (Fan et al, 2009; Fan et al, 2007). The Chinese State has significant influence over economic activity, whereas it is (usually) not the case in the USA. Ownership structure is highly concentrated in China and much more diffuse in the USA. The legal structure and origins in the USA is based on commonlaw whereas it is a variant of civil law in China. Property rights are well protected in the United States, but much less so in China. More generally, voice and accountability, the quality of government and regulation, and the control of corruption 
are all weaker in China. ${ }^{29}$ Also, the quality of accounting, auditing and earnings statements may be less in China compared to the US (DeFond, et al, 1999). Nevertheless, a comparison of executive pay between China and the USA is of interest. First, it helps shed some light on whether Chinese executive compensation design is converging to the western model. Second, it highlights differences in the drivers of executive pay in the two largest global economies. We perform an OLS regression of CEO pay on a US indicator variable, controlling for economic and corporate governance variables. ${ }^{30}$

To conduct a like-for-like comparison we calculated the average pay of the top three US officers using data from Execucomp, which reports executive compensation information for S\&P 1500 firms. A central concern is that the cost of living etc. is radically different between China and the USA. To partially reduce such concerns we adjusted the Chinese compensation data using Purchasing Power Parity exchange rates from the Penn World Tables. Using the PPP rates has the effect of increasing China's dollar denominated executive pay compared to using the standard exchange rate. $^{31}$

Table 8 contrasts executive pay in China with pay in US, denominated in US dollars. We find that US cash compensation is approximately 17 times that of China's executives over the sample period. However, if stock options and other equity pay earned by US CEOs are included in the measure of US pay, the ratio increases to

\footnotetext{
${ }^{29}$ For example, Transparency International provides a Corruption Perception Index that ranges from 0 to 10, with higher scores meaning less corruption. In 2005, the USA scored 7.6 and China 3.2; the relative global ranks were 17 for the USA and 78 for China, assessed from 158 nations.

${ }^{30}$ Fixed effects estimation is not possible in this context due to the lack of within firm variation in the country variable. Firms belong to either US or China and do not switch.

${ }^{31}$ The PPP rate is approximately $\$ 1: 2 \mathrm{RMB}$ compared to the official rate which is approximately \$1:7RMB.
} 
approximately $42 .{ }^{32}$ Overall, the raw data shows that US executives earn considerably more than their Chinese counterparts.

However, the descriptive statistics do not control for other factors. As shown in Table 8 (Panel B), there are significant differences between the US and China in terms of firm size, performance and corporate governance. Importantly, firm size (SALES) is significantly higher in the US. Since firm revenues are an important predictor of CEO pay it is important to control for this variable. Also, we note that stock returns are better in the US compared to China. US firms have a greater fraction of independent outsiders, are more likely to combine the posts of CEO and Chair, and are more apt to have a compensation committee.

Table 9 pools the US and China panel data. We regress the log of CEO pay on a US indicator variable, controlling for economic and boardroom variables as in our previous analysis. The independent variable of interest in Table 9 is the US indicator variable (=1 for USA and 0 for China) in columns 1 and 2. After controlling for economic factors (such as firm size, performance, growth opportunities), and board variables (such as board size, and leadership structure) we find that executive pay is significantly higher in the US compared to China. This finding is confirmed using both the salary plus bonus CEO pay measure (column 1) or the US total pay measure (column 2). The point estimate suggests that salary and bonus is approximately $775 \%$ higher in the US relative to China. ${ }^{33}$ When we use the US total pay measure, the USChina gap is even larger. However, the included variables are important in dampening the raw US-China executive pay differential. We ran a simple linear regression of $\log$ salary plus bonus on the US dummy variable alone. It yielded a point estimate of 2.9,

\footnotetext{
${ }^{32}$ The increase is automatic since China's executives do not receive options or restricted stock in this period so the denominator in the calculation remains the same.

${ }^{33}$ Calculated as $\mathrm{e}^{2.17}-1$.
} 
suggesting the mean US-China pay difference is about $1770 \%$ (i.e. $\mathrm{e}^{2.9}-1$ ). By including the explanatory variables in the regression model, therefore, we account for about half of the observed raw differences in cash compensation between the US and China. However, the gap is still appreciable.

We next inspected the pay models for each country separately to see if the effects of each covariate differed across countries. The results are contained in the final three columns of Table 9. Comparing the coefficient estimates across the two countries we find that firm size, firm stock returns, firm growth opportunities, and firm risk all have a larger impact on executive pay in the US compared to China. We conclude that the determinants of executive pay have a differential impact between the two countries. ${ }^{34}$ In addition, the US indicator variable remains significant in all equations, and quantitatively large.

We next tested for differences between US and China pay using the propensity score method (Rosenbaum and Rubin, 1983; Heckman et al, 19987, 1998). Propensity score matching can alleviate selection biases arising from the non-random assignment of data. It does so by optimally matching Chinese firms (the treatment condition) to US firms (the control condition). ${ }^{35}$ We matched like-for-like firms using a nearest

\footnotetext{
${ }^{34} \mathrm{We}$ also ran a regression of CEO pay on a full set of interactions between the US dummy variable and the economic and boardroom governance variables. In general, we found differential effects of the covariates on CEO pay in each country.

${ }^{35}$ Propensity matching potentially identifies causal differences between in pay between China and the US arising from the non-random data. Let $T_{i t}$ be a treatment indicator variable for firm $i$ at time $t$. Set $\mathrm{T}=0$ for the USA and $\mathrm{T}=1$ for China. Define $\mathrm{Y}_{\mathrm{it}}(1)$ as CEO pay if in China and $\mathrm{Y}_{\mathrm{it}}(0)$ if the USA. The causal effect on CEO pay is: $\mathrm{Y}_{\mathrm{it}}(1)-\mathrm{Y}_{\mathrm{it}}(0)$. The fundamental problem of causal inference is that the quantity $\mathrm{Y}_{\mathrm{it}}(0)$ is not observable. The pay received is not observable in the counterfactual state. The average treatment effect can be expressed as: $E\left[Y_{i t}(1)-Y_{i t}(0) \mid T_{i t}=1\right]=E\left[Y_{i t}(1) \mid T_{i t}=1\right]-E\left[Y_{i t}(0) \mid\right.$ $\left.\mathrm{T}_{\mathrm{it}}=1\right]$. The counterfactual is then estimated by the average outcome value for matching firms, i.e. $\mathrm{E}\left[\mathrm{Y}_{\mathrm{it}}(0) \mid \mathrm{T}_{\mathrm{it}}=0\right]$ using a logit propensity score model which we report. The effectiveness of the identification strategy in part depends on the success of the (logit) propensity score model to identify differences between the two economies. See Table 10 for the estimated propensity score logit model (Panel A). We could match 2211 firm-year observations on economic characteristics, and only 309 when matching on both economic and governance characteristics (Panel B).
} 
neighbor algorithm with caliper 0.05 , and no replacement. ${ }^{36} \mathrm{We}$ match the two samples based on two criteria: 1) matched on economic variables including sales, accounting and stock performance, market to book value and volatility 2) matched based on both economic and governance variables, including all economic variables listed above plus governance variables, board size, independent director, combine, and compensation committee.

The results are contained in Table 10. The left part of Panel A is the logistic equation that predicts the propensity score. It shows that firm size, stock returns, firm growth opportunities, firm risk, the presence of outside directors and independent compensation committees are all higher in the sample of US firms compared to China. The right part of Panel A shows the mean of the variables after matching. For example, once we match on both economic and corporate governance variables we see that there are few differences in size, performance, governance etc. between the US and China. The next step is to investigate any persistent differences in executive compensation. Panel B compares (log) compensation (of both total pay and salary plus bonus) in the US and China on the optimally matched firms. We find that differences in CEO pay (both mean and median) persist between China and the US even in the matched sample context. The propensity matching strategy confirms that US executives still receive significantly higher compensation than Chinese executives, controlling for economic, governance and industry differences between the two countries. For example, matching on economic and governance factors the average log compensation in China (the treatment group) is 4.37 . This compares to the US figure of 6.56 (the matched control group). The difference is statistically different. We therefore find that there are significant differences between executive

\footnotetext{
${ }^{36}$ Leuven, Edwin, and Barbara Sianesi (2003).
} 
pay in the US and China, even using propensity score methods to match firms with similar characteristics.

An important question is why US executives earn more than those in China? The standard economic variables used in our equations do not seem to eliminate all of the differences between the US and China, even though we controlled for differences in purchasing power. This suggests we have not controlled for all the relevant variables that drive compensation. At this stage we can only speculate on other potential reasons for these persistent differences in pay, and encourage further research on this topic.

First, it may be that US-China pay differences are not only restricted to top executives of companies. The best candidates in all professions (such as doctors, athletes, lawyers, bankers, and entertainers) all earn substantially more in the US than in China. Such wage premiums may reflect a much more active market for superstars in the United States (Rosen, 1981). It may be that all professions enjoy such differences.

Second, the culture of individualism is at the cornerstone of US society. US social norms often promote economic rewards arising from high levels of individual effort and risk bearing. As such the US may be characterized as a "winner-take-all" society (Frank and Cook, 1995). In addition, the existing evidence shows that incentives provided by corporate tournaments are much less pronounced in China than in market economies such as the US (Chen, Ezzamel and Cai, 2010) ${ }^{37}$.

Third, important differences may arise if compensation is not measured in exactly the same way across the different countries. One source of measurement bias

\footnotetext{
${ }^{37}$ Corporate tournaments are tested in a variety of ways. In particular, the size the 'prize' or pay gap between those at the top of the firm and those further down the hierarchy for 'winning' the corporate tournament is less in China compared to the US or UK.
} 
may be that Chinese executives enjoy considerable non-disclosed perks. Moreover, in discussing the wage differential between China and US, one should probably also consider social aspects such as, lack of medical expenses, school tuition fees and so on. This is partially controlled for using our PPP deflator that accounts for some of the differences in living standards. However, within the firm Chinese executives may enjoy substantial private benefits of control. Kato and Long (2006b) estimate that Chinese executive perks are about $15 \%$ to $32 \%$ of total compensation. Adithipyangkul et. al. (2010) estimate that the median value of perks (enjoyed by all company employees including management) are about 1.06 million RMB compared to total management compensation of 0.3 million $\mathrm{RMB} .{ }^{38} \mathrm{~A}$ challenge for future research, as compensation disclosure becomes better in China, is to more accurately calculate CEO pay.

Fourth, CEOs in the USA may face greater risk of being fired for poor performance compared to China CEOs and so require greater pay. Kaplan and Minton (2006) find in a sample of US firms that the CEO turnover rate is about $17.6 \%$ in recent times, and has been increasing. Also, the association between CEO turnover and firm performance has become stronger over time. This may provide some explanation for the significant difference in pay between the US and China. Possibly, if the pay is risk-adjusted (i.e. conditional on the probability of being fired) the difference is less striking. ${ }^{39}$

Finally, differences in US-China executive pay may arise because of differences in legal origins, culture and institutional arrangements between the two

\footnotetext{
${ }^{38}$ The average value of company-wide perks was even higher at 4.0 million RMB. However, these expenditures are spread across all employees within the firm.

${ }^{39}$ This is a potentially interesting avenue for future research. At present any differences are captured in the US-China indicator variable. We do note, however, that the frequency of CEO turnover in China appears to be greater than the US, making the job more risky, and not less so, other things equal.
} 
economies. These could include differences in regulatory regimes, tax and accounting rules. Understanding the degree of similarity, differences, and convergence in corporate governance regimes is, of course, complex (Yoshikawa and Rasheed, 2009).

\section{Conclusions}

In this paper we have investigated executive compensation and CEO share ownership in China's publically traded firms. As market reforms deepen we documented how firms provide incentives to their top executives. The drivers of executive compensation in China look surprising like that of western economies. We show that economic factors, such as firm size and performance, are important in China as they are in the US. We also show that corporate governance in China is mimicking important features of boards in the US, such as the adoption of independent directors and compensation committees. We document a number of salient findings.

First, we find that executive compensation is positively correlated to firm performance. The result is an agreement with agency theory. We stressed the importance of using firm fixed-effects to control for heterogeneity in firm and managerial quality. Second, we find that CEO share ownership is an important mechanism to align owner and managerial interests. The nominal value of CEO share ownership is significantly higher than executive cash compensation. Third, we show that executive pay and CEO ownership incentives are lower in State controlled firms and firms with concentrated ownership structures. Fourth, we find that boardroom governance is also important. Firms with more independent directors on the board have a higher pay-for-performance link. Fifth, we find that CEO turnover is negatively correlated to firm performance. CEOs in China are therefore disciplined for poor firm performance. Importantly, privately controlled firms and firms with 
more independent directors on the board are more likely to replace the CEO for poor performance. Finally, we document that US executive pay (salary and bonus) is about seventeen times higher than in China. Significant differences in US-China pay persist even after controlling for economic and governance factors. This suggests that unobserved variables such as social norms, institutions and private benefits of control in China might be important.

Often there is a suspicion that China's corporate governance reforms are merely window-dressing and ineffective. For years, investors criticized poor corporate governance structures and the lack of managerial incentives to promote shareholder value. Overall, our results suggest that, so far, China's corporate governance reforms have been helpful in aligning managerial interests with shareholders, although we think that the reforms could deepen further. One cautionary note is that our study was limited to 2001 to 2005 . Because new data on stock options and other equity pay has become available since 2006 we recommend further analysis in this area. Despite this, our study provides the first evidence comparing CEO pay in China to the US, as well as documenting the pay-for-performance relation after controlling for heterogeneity in firm and managerial quality. 


\section{Table 1}

Descriptive statistics: executive compensation Panel A

\begin{tabular}{|c|c|c|c|c|c|c|}
\hline Year & $\mathrm{N}$ & Mean & sd & $\begin{array}{l}\text { Lower } \\
\text { quartile }\end{array}$ & Median & $\begin{array}{l}\text { Upper } \\
\text { quartile }\end{array}$ \\
\hline 2001 & 1017 & 104975 & 217392 & 38467 & 71000 & 126000 \\
\hline 2002 & 1147 & 127558 & 127181 & 50516 & 90000 & 163333 \\
\hline 2003 & 1217 & 162881 & 153353 & 66800 & 120033 & 212667 \\
\hline 2004 & 1318 & 195745 & 183175 & 81667 & 146214 & 250667 \\
\hline 2005 & 1229 & 153512 & 194846 & 57567 & 107684 & 193333 \\
\hline Total & 5928 & 151477 & 179778 & 57333 & 106667 & 192700 \\
\hline \multicolumn{7}{|l|}{ Panel B } \\
\hline Industry & $\mathrm{N}$ & Mean & $\mathrm{sd}$ & $\begin{array}{l}\text { Lower } \\
\text { quartile }\end{array}$ & Median & $\begin{array}{l}\text { Upper } \\
\text { quartile }\end{array}$ \\
\hline Agriculture & 143 & 94667 & 62669 & 52400 & 80000 & 122533 \\
\hline Communicatio & 49 & 146733 & 109876 & 56000 & 133333 & 203333 \\
\hline Construction & 105 & 154867 & 120206 & 68825 & 132717 & 200000 \\
\hline Finance & 23 & 86030 & 57475 & 30000 & 73333 & 133200 \\
\hline $\begin{array}{l}\text { Information } \\
\text { Technology }\end{array}$ & 359 & 214219 & 217880 & 100000 & 160000 & 251000 \\
\hline Manufacturing & 3402 & 139662 & 193994 & 50533 & 93602 & 170167 \\
\hline Mining & 95 & 126937 & 96534 & 57333 & 106667 & 152081 \\
\hline Others & 369 & 153411 & 120238 & 66000 & 123000 & 200000 \\
\hline Real estate & 276 & 183101 & 183907 & 62200 & 129500 & 261717 \\
\hline Services & 173 & 208055 & 199898 & 83000 & 149329 & 273868 \\
\hline Transportation & 247 & 171156 & 137938 & 67948 & 122033 & 223333 \\
\hline Utilities & 251 & 166132 & 151276 & 68155 & 123333 & 213333 \\
\hline $\begin{array}{l}\text { Wholesale \& } \\
\text { Retail }\end{array}$ & 436 & 155455 & 132128 & 64000 & 115808 & 206667 \\
\hline Total & 5928 & 151477 & 179778 & 57333 & 106667 & 192700 \\
\hline
\end{tabular}

Executive Compensation is average executive compensation. It is the sum of three highest paid executive members' total compensation disclosed a single number divided by three. Executive compensation is calculated as the sum of basic salary, bonus, stipends, and other benefits. Executive compensation is denominated in Chinese RMB. 
Table 2

Descriptive statistics: Compensation, ownership and control

Panel A: Executive compensation and boardroom structure

\begin{tabular}{|c|c|c|c|c|c|c|}
\hline Year & $\begin{array}{l}\text { PAY } \\
\text { (RMB } \\
000 \text { s) }\end{array}$ & $\begin{array}{l}\mathrm{CEO} \\
\mathrm{OWN} \\
(\mathrm{RMB} \\
000 \mathrm{~s})\end{array}$ & $\begin{array}{l}\text { BOARD } \\
\text { SIZE }\end{array}$ & $\begin{array}{l}\text { IND_DIR } \\
(\%)\end{array}$ & COMBINE & $\begin{array}{l}\text { COMP } \\
\text { COM }\end{array}$ \\
\hline 2001 & 104.97 & 767.30 & 9.40 & 5.97 & 0.12 & 0.08 \\
\hline 2002 & 127.56 & 1375.27 & 9.92 & 23.65 & 0.11 & 0.31 \\
\hline 2003 & 162.88 & 1979.39 & 9.89 & 32.36 & 0.11 & 0.42 \\
\hline 2004 & 195.75 & 3285.02 & 9.80 & 33.82 & 0.11 & 0.46 \\
\hline 2005 & 153.51 & 3150.18 & 9.66 & 34.34 & 0.11 & 0.51 \\
\hline Total & 151.48 & 2187.57 & 9.74 & 26.88 & 0.11 & 0.37 \\
\hline
\end{tabular}

Panel B: Ownership

\begin{tabular}{lrrrrrr}
\hline Year & STATE & PRIVATE & OTHER & LG1_OWN & LG2_OWN & LG3_OWN \\
& & & & & & \\
2001 & 0.82 & 0.11 & 0.07 & 0.44 & 0.08 & 0.03 \\
2002 & 0.78 & 0.16 & 0.06 & 0.44 & 0.09 & 0.03 \\
2003 & 0.74 & 0.22 & 0.04 & 0.43 & 0.09 & 0.04 \\
2004 & 0.70 & 0.26 & 0.04 & 0.42 & 0.10 & 0.04 \\
2005 & 0.71 & 0.27 & 0.02 & 0.41 & 0.10 & 0.04 \\
& & & & & & \\
Total & 0.74 & 0.21 & 0.05 & 0.43 & 0.09 & 0.04 \\
\hline
\end{tabular}

Panel A: PAY: CEO cash pay (RMB 000s); CEO_OWN (RMB 000s): value of CEO shareholdings is the number of shares held by the CEO multiplied by the firms stock price (units = millions). IND_DIR: the fraction of the board comprised of independent directors; BOARD_SIZE: Board size is measured as the number of individuals on the main board. COMBINE: leadership structure of the firm is a dummy variable set equal to one if the posts of CEO and chairman are combined, and zero otherwise; COMP_COMM: a dummy variable equal to one if the firm has a compensation committee and zero otherwise. STATE=1 if the Chinese State is the ultimate firm owner. PRIVATE $=1$ if the ultimate owner is a private institution; OTHER is the residual ownership category. LG1_OWN: the percentage ownership of largest shareholder. LG2_OWN and LG3_OWN are the second and third largest ownership percentages. 
Table 3

Correlation matrix

\begin{tabular}{|c|c|c|c|c|c|c|c|c|c|c|c|c|c|c|c|}
\hline & Variable & Mean & $\mathrm{sd}$ & 1 & 2 & 3 & 4 & 5 & 6 & 7 & 8 & 9 & 10 & 11 & 12 \\
\hline 1 & $\operatorname{Ln}(\mathrm{PAY})$ & 11.54 & 0.89 & 1.00 & & & & & & & & & & & \\
\hline 2 & ANNRET & -0.16 & 0.24 & 0.17 & 1.00 & & & & & & & & & & \\
\hline 3 & ROA & 0.01 & 0.28 & 0.13 & 0.17 & 1.00 & & & & & & & & & \\
\hline 4 & LSALES & 20.32 & 1.39 & 0.39 & 0.25 & 0.22 & 1.00 & & & & & & & & \\
\hline 5 & MKT_BK & 1.57 & 1.40 & -0.14 & 0.08 & -0.26 & -0.37 & 1.00 & & & & & & & \\
\hline 6 & VOL & -1.15 & 0.35 & -0.07 & -0.06 & -0.13 & -0.16 & -0.07 & 1.00 & & & & & & \\
\hline 7 & STATE & 0.74 & 0.44 & 0.00 & 0.04 & 0.09 & 0.22 & -0.04 & -0.08 & 1.00 & & & & & \\
\hline 8 & LG1_OWN & 0.43 & 0.17 & -0.05 & 0.10 & 0.10 & 0.26 & 0.00 & -0.12 & 0.33 & 1.00 & & & & \\
\hline 9 & IND_DIR & 26.88 & 12.64 & 0.21 & 0.11 & -0.03 & 0.08 & -0.32 & 0.14 & -0.14 & -0.06 & 1.00 & & & \\
\hline 10 & BOARD_SIZE & 9.74 & 2.26 & 0.12 & 0.05 & 0.04 & 0.21 & -0.08 & -0.05 & 0.13 & 0.00 & -0.05 & 1.00 & & \\
\hline 11 & COMBINE & 0.11 & 0.31 & 0.02 & 0.00 & -0.01 & -0.03 & 0.03 & 0.00 & -0.05 & -0.03 & 0.01 & -0.04 & 1.00 & \\
\hline 12 & COMP COMM & 0.37 & 0.48 & 0.15 & 0.05 & 0.01 & 0.07 & -0.14 & 0.04 & 0.04 & -0.04 & 0.26 & 0.08 & -0.01 & 1.00 \\
\hline
\end{tabular}

$\mathrm{Ln}(\mathrm{PAY})$ is the log of executive pay. SHR: annual shareholder returns; ROA: Return on assets; SALES: log of firm sales; MKT BK: market value of the firm divided by the book value of assets; VOL: natural $\log$ of the standard deviation of stock returns over the year. STATE: dummy variable equal to one if the firm's ultimate owner is the Chinese State, and zero otherwise; LG1 OWN: Percentage share ownership of the largest shareholder; IND DIR: the fraction of the board comprised of independent directors; BOARD_SIZE: Board size is measured as the number of individuals on the main board. COMBINE: leadership structure of the firm is a dummy variable set equal to one if the posts of CEO and chairman are combined, and zero otherwise; COMP_COMM: a dummy variable equal to one if the firm has a compensation committee and zero otherwise. 
Table 4

Executive compensation regressions: China 2001 to 2005

\begin{tabular}{|c|c|c|c|c|c|}
\hline & (1) & (2) & (3) & (4) & (5) \\
\hline & $\begin{array}{l}\ln (\mathrm{PAY}) \\
\text { Pooled OLS }\end{array}$ & $\begin{array}{l}\ln (\text { PAY }) \\
\text { Random } \\
\text { Effects. } \\
\text { Current } \\
\text { performance }\end{array}$ & $\begin{array}{l}\ln (\mathrm{PAY}) \\
\text { Fixed } \\
\text { Effects. } \\
\text { Current } \\
\text { performance }\end{array}$ & $\begin{array}{l}\ln (\mathrm{PAY}) \\
\text { Random } \\
\text { Effects } \\
\text { Lagged } \\
\text { performance }\end{array}$ & $\begin{array}{l}\ln (\mathrm{PAY}) \\
\text { Fixed } \\
\text { Effects. } \\
\text { Lagged } \\
\text { performance }\end{array}$ \\
\hline SHR & $\begin{array}{l}0.14 * * * \\
(2.79)\end{array}$ & $\begin{array}{l}0.01 \\
(0.33)\end{array}$ & $\begin{array}{l}-0.02 \\
(-0.63)\end{array}$ & $\begin{array}{l}0.05^{*} \\
(1.79)\end{array}$ & $\begin{array}{l}0.05 * \\
(1.66)\end{array}$ \\
\hline ROA & $\begin{array}{l}0.21 * * * \\
(3.28)\end{array}$ & $\begin{array}{l}0.14 * * * \\
(3.60)\end{array}$ & $\begin{array}{l}0.14 * * * \\
(3.65)\end{array}$ & $\begin{array}{l}0.08 * * \\
(2.21)\end{array}$ & $\begin{array}{l}0.06 \\
(1.62)\end{array}$ \\
\hline SALES & $\begin{array}{l}0.28 * * * \\
(22.90)\end{array}$ & $\begin{array}{l}0.21 * * * \\
(10.03)\end{array}$ & $\begin{array}{l}0.14 * * * \\
(4.88)\end{array}$ & $\begin{array}{l}0.21 * * * \\
(9.86)\end{array}$ & $\begin{array}{l}0.14 * * * \\
(4.67)\end{array}$ \\
\hline MKT_BK & $\begin{array}{l}0.06 * * * \\
(4.07)\end{array}$ & $\begin{array}{l}0.04 * * \\
(2.24)\end{array}$ & $\begin{array}{l}0.03 * * \\
(2.23)\end{array}$ & $\begin{array}{l}0.02 \\
(1.17)\end{array}$ & $\begin{array}{l}0.01 \\
(0.91)\end{array}$ \\
\hline VOL & $\begin{array}{l}-0.07 * * \\
(-2.03)\end{array}$ & $\begin{array}{l}-0.03 \\
(-1.16)\end{array}$ & $\begin{array}{l}-0.02 \\
(-0.61)\end{array}$ & $\begin{array}{l}-0.04 \\
(-1.27)\end{array}$ & $\begin{array}{l}-0.02 \\
(-0.83)\end{array}$ \\
\hline STATE & $\begin{array}{l}-0.05 * * \\
(-2.06)\end{array}$ & $\begin{array}{l}-0.06 * \\
(-1.77)\end{array}$ & $\begin{array}{l}-0.07 \\
(-1.56)\end{array}$ & $\begin{array}{l}-0.04 \\
(-1.07)\end{array}$ & $\begin{array}{l}-0.05 \\
(-1.06)\end{array}$ \\
\hline LG1_OWN & $\begin{array}{l}-0.67 * * * \\
(-9.88)\end{array}$ & $\begin{array}{l}-0.50 * * * \\
(-4.55)\end{array}$ & $\begin{array}{l}-0.44 * * \\
(-2.22)\end{array}$ & $\begin{array}{l}-0.52 * * * \\
(-4.65)\end{array}$ & $\begin{array}{l}-0.49 * * \\
(-2.44)\end{array}$ \\
\hline IND_DIR & $\begin{array}{l}0.01 * * * \\
(3.74)\end{array}$ & $\begin{array}{l}0.00 \\
(1.55)\end{array}$ & $\begin{array}{l}0.00 \\
(0.74)\end{array}$ & $\begin{array}{l}0.00 \\
(1.63)\end{array}$ & $\begin{array}{l}0.00 \\
(0.95)\end{array}$ \\
\hline BOARD_SIZE & $\begin{array}{l}0.01 \\
(1.16)\end{array}$ & $\begin{array}{l}0.00 \\
(0.76)\end{array}$ & $\begin{array}{l}-0.00 \\
(-0.07)\end{array}$ & $\begin{array}{l}0.01 \\
(1.02)\end{array}$ & $\begin{array}{l}0.00 \\
(0.14)\end{array}$ \\
\hline COMBINE & $\begin{array}{l}0.09 * * * \\
(2.99)\end{array}$ & $\begin{array}{l}0.05 \\
(1.49)\end{array}$ & $\begin{array}{l}0.03 \\
(0.72)\end{array}$ & $\begin{array}{l}0.06 \\
(1.60)\end{array}$ & $\begin{array}{l}0.04 \\
(0.90)\end{array}$ \\
\hline COMP_COMM & $\begin{array}{l}0.12 * * * \\
(5.50)\end{array}$ & $\begin{array}{l}0.10 * * * \\
(4.00)\end{array}$ & $\begin{array}{l}0.10 * * * \\
(3.31)\end{array}$ & $\begin{array}{l}0.11 * * * \\
(3.99)\end{array}$ & $\begin{array}{l}0.10 * * * \\
(3.11)\end{array}$ \\
\hline Constant & $\begin{array}{l}5.24 * * * \\
(17.14)\end{array}$ & $\begin{array}{l}7.11 * * * \\
(17.24)\end{array}$ & $\begin{array}{l}8.51 * * * \\
(14.82)\end{array}$ & $\begin{array}{l}7.09 * * * \\
(17.32)\end{array}$ & $\begin{array}{l}8.58 * * * \\
(14.78)\end{array}$ \\
\hline Observations & 5928 & 5928 & 5928 & 5653 & 5653 \\
\hline R-squared & 0.29 & . & 0.26 & . & 0.25 \\
\hline Industry effects & Yes & Yes & No & Yes & No \\
\hline Time effects & Yes & Yes & Yes & Yes & Yes \\
\hline $\begin{array}{l}\text { Number of } \\
\text { firms }\end{array}$ & 1342 & 1342 & 1342 & 1342 & 1342 \\
\hline
\end{tabular}

Variable definitions: The dependent variable $\ln (\mathrm{PAY})$ is the $\log$ of executive pay. The independent variables are: SHR: annual shareholder returns; ROA: Return on assets; SALES: log of firm sales; MKT BK: market value of the firm divided by the book value of assets; VOL: natural log of the standard deviation of stock returns over the year. STATE: dummy variable equal to one if the firm's ultimate owner is the Chinese State, and zero otherwise; LG1_OWN: Percentage share ownership of the largest shareholder; IND_DIR: the fraction of the board comprised of independent directors; BOARD_SIZE: Board size is measured as the number of individuals on the main board. COMBINE: leadership structure of the firm is a dummy variable set equal to one if the posts of CEO and chairman are combined, and zero otherwise; COMP_COMM: a dummy variable equal to one if the firm has a compensation committee and zero otherwise. The regressions contain a set of 13 industry variables and a set of 4 time dummies, from 2002 to 2005, with 2001 as the base year. Coefficients on the industry and time dummies are suppressed for expositional convenience. ${ }^{* * *} \mathrm{p}<0.01, * *$ $\mathrm{p}<0.05, * \mathrm{p}<0.1$. Standard errors are adjusted and clustered on the firm identifier. 
Table 5

CEO share ownership and firm performance in China's publicly traded firms

\begin{tabular}{|c|c|c|c|c|c|}
\hline VARIABLES & $\begin{array}{l}\text { (1) } \\
\text { CEO_OWN } \\
\text { Pooled OLS }\end{array}$ & $\begin{array}{l}(2) \\
\text { CEO_OWN } \\
\text { Random } \\
\text { Effects. } \\
\text { Current } \\
\text { performance }\end{array}$ & $\begin{array}{l}(3) \\
\text { CEO_OWN } \\
\text { Fixed } \\
\text { Effects. } \\
\text { Current } \\
\text { performance }\end{array}$ & $\begin{array}{l}(4) \\
\text { CEO_OWN } \\
\text { Random } \\
\text { Effects. } \\
\text { Lagged } \\
\text { performance }\end{array}$ & $\begin{array}{l}(5) \\
\text { CEO_OWN } \\
\text { Fixed } \\
\text { Effects. } \\
\text { Lagged } \\
\text { performance }\end{array}$ \\
\hline SHR & $\begin{array}{l}0.13 * * * \\
(3.36)\end{array}$ & $\begin{array}{l}-0.00 \\
(-0.16)\end{array}$ & $\begin{array}{l}-0.01 \\
(-0.50)\end{array}$ & $\begin{array}{l}0.02 * \\
(1.85)\end{array}$ & $\begin{array}{l}0.02 * \\
(1.77)\end{array}$ \\
\hline ROA & $\begin{array}{l}0.13 * * * \\
(4.95)\end{array}$ & $\begin{array}{l}0.03^{*} \\
(1.90)\end{array}$ & $\begin{array}{l}0.02 \\
(1.28)\end{array}$ & $\begin{array}{l}0.01 * * * \\
(2.96)\end{array}$ & $\begin{array}{l}0.01 * * \\
(2.00)\end{array}$ \\
\hline SALES & $\begin{array}{l}0.02 * * * \\
(3.54)\end{array}$ & $\begin{array}{l}0.01 \\
(1.41)\end{array}$ & $\begin{array}{l}0.01 * \\
(1.67)\end{array}$ & $\begin{array}{l}0.00 \\
(1.57)\end{array}$ & $\begin{array}{l}0.01 * \\
(1.93)\end{array}$ \\
\hline MKT_BK & $\begin{array}{l}0.03 * * * \\
(3.95)\end{array}$ & $\begin{array}{l}0.01 * * \\
(2.06)\end{array}$ & $\begin{array}{l}0.01 \\
(1.54)\end{array}$ & $\begin{array}{l}0.01 \\
(1.27)\end{array}$ & $\begin{array}{l}0.00 \\
(0.92)\end{array}$ \\
\hline VOL & $\begin{array}{l}-0.02 \\
(-0.65)\end{array}$ & $\begin{array}{l}-0.03 \\
(-1.62)\end{array}$ & $\begin{array}{l}-0.03 * \\
(-1.67)\end{array}$ & $\begin{array}{l}-0.00 \\
(-0.12)\end{array}$ & $\begin{array}{l}-0.00 \\
(-0.43)\end{array}$ \\
\hline STATE & $\begin{array}{l}-0.18 * * * \\
(-7.38)\end{array}$ & $\begin{array}{l}-0.05 * * * \\
(-3.42)\end{array}$ & $\begin{array}{l}-0.01 \\
(-0.43)\end{array}$ & $\begin{array}{l}-0.03 * * \\
(-2.20)\end{array}$ & $\begin{array}{l}0.00 \\
(0.32)\end{array}$ \\
\hline LG1_OWN & $\begin{array}{l}-0.41 * * * \\
(-7.79)\end{array}$ & $\begin{array}{l}-0.31 * * * \\
(-3.40)\end{array}$ & $\begin{array}{l}-0.10 \\
(-0.90)\end{array}$ & $\begin{array}{l}-0.15^{*} \\
(-1.90)\end{array}$ & $\begin{array}{l}0.00 \\
(0.03)\end{array}$ \\
\hline IND_DIR & $\begin{array}{l}0.00 \\
(0.67)\end{array}$ & $\begin{array}{l}-0.00 \\
(-0.52)\end{array}$ & $\begin{array}{l}-0.00 \\
(-0.61)\end{array}$ & $\begin{array}{l}0.00 \\
(0.12)\end{array}$ & $\begin{array}{l}0.00 \\
(0.00)\end{array}$ \\
\hline BOARD_SIZE & $\begin{array}{l}-0.00 \\
(-0.21)\end{array}$ & $\begin{array}{l}0.00 \\
(1.14)\end{array}$ & $\begin{array}{l}0.00 \\
(1.47)\end{array}$ & $\begin{array}{l}0.00 \\
(1.24)\end{array}$ & $\begin{array}{l}0.00 \\
(1.44)\end{array}$ \\
\hline COMBINE & $\begin{array}{l}0.17 * * * \\
(4.53)\end{array}$ & $\begin{array}{l}0.12 * * * \\
(3.30)\end{array}$ & $\begin{array}{l}0.10 * * * \\
(2.90)\end{array}$ & $\begin{array}{l}0.09 * * * \\
(3.01)\end{array}$ & $\begin{array}{l}0.08 * * * \\
(2.60)\end{array}$ \\
\hline COMP_COMM & $\begin{array}{l}0.00 \\
(0.02)\end{array}$ & $\begin{array}{l}-0.01 \\
(-0.79)\end{array}$ & $\begin{array}{l}-0.01 \\
(-0.50)\end{array}$ & $\begin{array}{l}-0.02 \\
(-1.27)\end{array}$ & $\begin{array}{l}-0.02 \\
(-1.14)\end{array}$ \\
\hline Constant & $\begin{array}{l}-0.09 \\
(-0.73)\end{array}$ & $\begin{array}{l}0.00 \\
(0.01)\end{array}$ & $\begin{array}{l}-0.08 \\
(-0.66)\end{array}$ & $\begin{array}{l}0.03 \\
(0.35)\end{array}$ & $\begin{array}{l}-0.04 \\
(-0.47)\end{array}$ \\
\hline Observations & 5928 & 5928 & 5928 & 5653 & 5653 \\
\hline $\begin{array}{l}\text { Number of } \\
\text { firms }\end{array}$ & 1342 & 1342 & 1342 & 1342 & 1342 \\
\hline Industry effects & Yes & Yes & No & Yes & No \\
\hline Time effects & Yes & Yes & Yes & Yes & Yes \\
\hline R-squared & 0.06 & . & 0.02 & . & 0.03 \\
\hline
\end{tabular}

Variable definitions: The dependent variable CEO OWN is the log of $(1+$ the value of the CEO share ownership). SHR: annual shareholder returns; ROA: Return on assets; SALES: $\log$ of firm sales; MKT_BK: market value of the firm divided by the book value of assets; VOL: natural log of the standard deviation of stock returns over the year. STATE: dummy variable equal to one if the firm's ultimate owner is the Chinese State, and zero otherwise; LG1_OWN: Percentage share ownership of the largest shareholder; IND_DIR: the fraction of the board comprised of independent directors; BOARD_SIZE: Board size is measured as the number of individuals on the main board. COMBINE: leadership structure of the firm is a dummy variable set equal to one if the posts of CEO and chairman are combined, and zero otherwise; COMP_COMM: a dummy variable equal to one if the firm has a compensation committee and zero otherwise. The regressions contain a set of 13 industry variables and a set of 4 time dummies, from 2002 to 2005, with 2001 as the base year. Coefficients on the industry and dummies are suppressed for expositional convenience. ${ }^{* * *} \mathrm{p}<0.01,{ }^{* *} \mathrm{p}<0.05$, * $\mathrm{p}<0.1$. Standard errors are adjusted and clustered on the firm identifier. 
Table 6

Pay-for-performance sensitivities in China's publicly traded firms

\begin{tabular}{|c|c|c|c|c|c|}
\hline & $\begin{array}{l}(1) \\
\Delta \ln (\mathrm{PAY}) \\
\text { All Firms }\end{array}$ & $\begin{array}{l}(2) \\
\Delta \ln (\mathrm{PAY}) \\
\text { State } \\
\text { controlled } \\
\text { firms }\end{array}$ & $\begin{array}{l}(3) \\
\Delta \ln (\mathrm{PAY}) \\
\text { Non-State } \\
\text { controlled } \\
\text { firms }\end{array}$ & $\begin{array}{l}(4) \\
\Delta \ln (\mathrm{PAY}) \\
\text { Independent } \\
\text { Directors } \\
\geq 25 \%\end{array}$ & $\begin{array}{l}(5) \\
\Delta \ln (\mathrm{PAY}) \\
\text { Independent } \\
\text { Directors } \\
<25 \%\end{array}$ \\
\hline$\Delta \ln (\mathrm{SW})$ & $\begin{array}{l}0.18 * * * \\
(5.06)\end{array}$ & $\begin{array}{l}0.23 * * * \\
(5.36)\end{array}$ & $\begin{array}{l}0.13^{*} \\
(1.70)\end{array}$ & $\begin{array}{l}0.18 * * * \\
(4.87)\end{array}$ & $\begin{array}{l}0.19 \\
(1.42)\end{array}$ \\
\hline$\triangle \mathrm{ROA}$ & $\begin{array}{l}0.05^{*} \\
(1.75)\end{array}$ & $\begin{array}{l}0.03 \\
(0.75)\end{array}$ & $\begin{array}{l}0.05 \\
(1.29)\end{array}$ & $\begin{array}{l}0.04 \\
(1.30)\end{array}$ & $\begin{array}{l}0.17^{*} \\
(1.75)\end{array}$ \\
\hline$\triangle$ SALES & $\begin{array}{l}0.09 * * * \\
(6.17)\end{array}$ & $\begin{array}{l}0.08^{* * * *} \\
(3.90)\end{array}$ & $\begin{array}{l}0.10^{* * *} \\
(4.03)\end{array}$ & $\begin{array}{l}0.09^{* * *} \\
(5.80)\end{array}$ & $\begin{array}{l}0.14 * * \\
(2.45)\end{array}$ \\
\hline$\Delta \mathrm{MKT} \_\mathrm{BK}$ & $\begin{array}{l}-0.02 \\
(-1.39)\end{array}$ & $\begin{array}{l}-0.04 * * \\
(-2.25)\end{array}$ & $\begin{array}{l}-0.01 \\
(-0.61)\end{array}$ & $\begin{array}{l}-0.02 \\
(-1.53)\end{array}$ & $\begin{array}{l}0.00 \\
(0.06)\end{array}$ \\
\hline$\Delta \mathrm{VOL}$ & $\begin{array}{l}-0.01 \\
(-0.70)\end{array}$ & $\begin{array}{l}-0.02 \\
(-0.77)\end{array}$ & $\begin{array}{l}-0.01 \\
(-0.28)\end{array}$ & $\begin{array}{l}-0.01 \\
(-0.50)\end{array}$ & $\begin{array}{l}-0.04 \\
(-0.62)\end{array}$ \\
\hline$\triangle \mathrm{STATE}$ & $\begin{array}{l}-0.08^{* *} \\
(-2.48)\end{array}$ & $\begin{array}{l}-0.19 * * * \\
(-3.25)\end{array}$ & $\begin{array}{l}-0.10^{* *} \\
(-2.10)\end{array}$ & $\begin{array}{l}-0.08^{* *} \\
(-2.28)\end{array}$ & $\begin{array}{l}-0.06 \\
(-0.46)\end{array}$ \\
\hline$\Delta \mathrm{LG} 1 \_\mathrm{OWN}$ & $\begin{array}{l}0.04 \\
(0.25)\end{array}$ & $\begin{array}{l}-0.13 \\
(-0.67)\end{array}$ & $\begin{array}{l}0.36 \\
(1.20)\end{array}$ & $\begin{array}{l}0.11 \\
(0.67)\end{array}$ & $\begin{array}{l}-0.92 \\
(-1.63)\end{array}$ \\
\hline$\Delta \mathrm{IND} \_\mathrm{DIR}$ & $\begin{array}{l}0.00 \\
(0.52)\end{array}$ & $\begin{array}{l}-0.00 \\
(-0.83)\end{array}$ & $\begin{array}{l}0.00^{*} \\
(1.76)\end{array}$ & $\begin{array}{l}0.00 \\
(0.86)\end{array}$ & $\begin{array}{l}-0.00 \\
(-0.67)\end{array}$ \\
\hline$\triangle$ BOARD_SIZE & $\begin{array}{l}0.01 \\
(1.13)\end{array}$ & $\begin{array}{l}0.00 \\
(0.78)\end{array}$ & $\begin{array}{l}0.01 \\
(0.81)\end{array}$ & $\begin{array}{l}0.00 \\
(0.55)\end{array}$ & $\begin{array}{l}0.03^{*} \\
(1.86)\end{array}$ \\
\hline$\triangle \mathrm{COMBINE}$ & $\begin{array}{l}0.02 \\
(0.68)\end{array}$ & $\begin{array}{l}0.07 * \\
(1.73)\end{array}$ & $\begin{array}{l}-0.03 \\
(-0.61)\end{array}$ & $\begin{array}{l}0.02 \\
(0.71)\end{array}$ & $\begin{array}{l}0.02 \\
(0.15)\end{array}$ \\
\hline$\triangle \mathrm{COMP} C \mathrm{COMM}$ & $\begin{array}{l}0.07 * * \\
(2.49)\end{array}$ & $\begin{array}{l}0.08^{* * *} \\
(2.75)\end{array}$ & $\begin{array}{l}0.04 \\
(0.67)\end{array}$ & $\begin{array}{l}0.05^{*} \\
(1.71)\end{array}$ & $\begin{array}{l}0.17 * * \\
(2.55)\end{array}$ \\
\hline Constant & $\begin{array}{l}-0.28^{* *} \\
(-2.18)\end{array}$ & $\begin{array}{l}0.27 * * \\
(2.14)\end{array}$ & $\begin{array}{l}-0.02 \\
(-0.08)\end{array}$ & $\begin{array}{l}0.23 \\
(1.64)\end{array}$ & $\begin{array}{l}-0.39 \\
(-1.62)\end{array}$ \\
\hline $\begin{array}{l}\text { Industry \& time } \\
\text { effects }\end{array}$ & Yes & Yes & Yes & Yes & Yes \\
\hline Observations & 4586 & 3362 & 1224 & 4139 & 447 \\
\hline R-squared & 0.20 & 0.18 & 0.28 & 0.21 & 0.11 \\
\hline
\end{tabular}

The dependent variable $\Delta \ln (\mathrm{PAY})$ is the change log of executive cash pay. $\Delta \ln (\mathrm{SW})$ is the change in shareholder wealth and is equal to the continuously accrued rate of return on common stock; $\triangle \mathrm{ROA}$ : is the change in return on assets; $\triangle$ SALES: is the change in the log of firm sales. $\Delta$ is the first-difference operator and is applied to other right-hand side variables too. MKT_BK: market value of the firm divided by the book value of assets; VOL: natural $\log$ of the standard deviation of stock returns over the year. STATE: dummy variable equal to one if the firm's ultimate owner is the Chinese State, and zero otherwise; LG1_OWN: Percentage share ownership of the largest shareholder; IND DIR: the fraction of the board comprised of independent directors; BOARD_SIZE: Board size is measured as the number of individuals on the main board. COMBINE: leadership structure of the firm is a dummy variable set equal to one if the posts of CEO and chairman are combined, and zero otherwise; COMP_COMM: a dummy variable equal to one if the firm has a compensation committee and zero otherwise. The regressions contain a set of 13 industry variables and a set of time dummies. Standard errors are adjusted and clustered on the firm identifier. 
Table 7

CEO Turnover in China

\begin{tabular}{|c|c|c|c|c|c|}
\hline VARIABLES & $\begin{array}{l}(1) \\
\mathrm{CEO} \_\mathrm{CH} \\
\text { All Firms }\end{array}$ & $\begin{array}{l}\text { (2) } \\
\text { CEO_CH } \\
\text { State } \\
\text { controlled } \\
\text { firms }\end{array}$ & $\begin{array}{l}(3) \\
\text { CEO_CH } \\
\text { Non-State } \\
\text { controlled } \\
\text { firms } \\
\end{array}$ & $\begin{array}{l}(4) \\
\text { CEO_CH } \\
\text { Independent } \\
\text { Directors } \\
\geq 25 \%\end{array}$ & $\begin{array}{l}(5) \\
\text { CEO_CH } \\
\text { Independent } \\
\text { Directors } \\
<25 \%\end{array}$ \\
\hline SHR & $\begin{array}{l}-0.06 * * \\
(-2.25)\end{array}$ & $\begin{array}{l}-0.04 \\
(-1.12)\end{array}$ & $\begin{array}{l}-0.13 * * \\
(-2.14)\end{array}$ & $\begin{array}{l}-0.08 * * \\
(-2.53)\end{array}$ & $\begin{array}{l}-0.00 \\
(-0.06)\end{array}$ \\
\hline ROA & $\begin{array}{l}-0.05 \\
(-1.50)\end{array}$ & $\begin{array}{l}-0.13 * * \\
(-2.20)\end{array}$ & $\begin{array}{l}-0.00 \\
(-0.03)\end{array}$ & $\begin{array}{l}-0.05 \\
(-1.21)\end{array}$ & $\begin{array}{l}-0.04 \\
(-0.83)\end{array}$ \\
\hline SALES & $\begin{array}{l}-0.02 * * * \\
(-3.03)\end{array}$ & $\begin{array}{l}-0.01 \\
(-1.29)\end{array}$ & $\begin{array}{l}-0.04 * * * \\
(-3.46)\end{array}$ & $\begin{array}{l}-0.02 * * \\
(-2.38)\end{array}$ & $\begin{array}{l}-0.02 * \\
(-1.76)\end{array}$ \\
\hline MKT_BK & $\begin{array}{l}0.00 \\
(0.35)\end{array}$ & $\begin{array}{l}0.00 \\
(0.08)\end{array}$ & $\begin{array}{l}0.00 \\
(0.51)\end{array}$ & $\begin{array}{l}0.00 \\
(0.57)\end{array}$ & $\begin{array}{l}-0.00 \\
(-0.45)\end{array}$ \\
\hline VOL & $\begin{array}{l}0.11 * * * \\
(5.55)\end{array}$ & $\begin{array}{l}0.10 * * * \\
(4.41)\end{array}$ & $\begin{array}{l}0.11 * * * \\
(2.84)\end{array}$ & $\begin{array}{l}0.09 * * * \\
(3.66)\end{array}$ & $\begin{array}{l}0.16 * * * \\
(4.30)\end{array}$ \\
\hline STATE & $\begin{array}{l}-0.03^{*} \\
(-1.68)\end{array}$ & & & $\begin{array}{l}-0.01 \\
(-0.66)\end{array}$ & $\begin{array}{l}-0.08 * * \\
(-2.47)\end{array}$ \\
\hline LG1_OWN & $\begin{array}{l}-0.03 \\
(-0.66)\end{array}$ & $\begin{array}{l}-0.03 \\
(-0.67)\end{array}$ & $\begin{array}{l}-0.05 \\
(-0.53)\end{array}$ & $\begin{array}{l}0.02 \\
(0.48)\end{array}$ & $\begin{array}{l}-0.11 \\
(-1.54)\end{array}$ \\
\hline IND_DIR & $\begin{array}{l}0.00 \\
(0.83)\end{array}$ & $\begin{array}{l}0.00 \\
(0.84)\end{array}$ & $\begin{array}{l}-0.00 \\
(-0.02)\end{array}$ & $\begin{array}{l}0.00 \\
(1.26)\end{array}$ & $\begin{array}{l}-0.00 \\
(-0.55)\end{array}$ \\
\hline BOARD_SIZE & $\begin{array}{l}-0.01 * \\
(-1.87)\end{array}$ & $\begin{array}{l}-0.00 \\
(-1.33)\end{array}$ & $\begin{array}{l}-0.01 * \\
(-1.87)\end{array}$ & $\begin{array}{l}-0.01 * \\
(-1.93)\end{array}$ & $\begin{array}{l}-0.00 \\
(-0.72)\end{array}$ \\
\hline COMBINE & $\begin{array}{l}-0.13 * * * \\
(-6.76)\end{array}$ & $\begin{array}{l}-0.13 * * * \\
(-5.97)\end{array}$ & $\begin{array}{l}-0.12 * * * \\
(-3.22)\end{array}$ & $\begin{array}{l}-0.09 * * * \\
(-4.08)\end{array}$ & $\begin{array}{l}-0.20 * * * \\
(-5.78)\end{array}$ \\
\hline COMP_COMM & $\begin{array}{l}0.02 \\
(1.19)\end{array}$ & $\begin{array}{l}0.02 \\
(1.43)\end{array}$ & $\begin{array}{l}0.00 \\
(0.07)\end{array}$ & $\begin{array}{l}0.02 \\
(1.61)\end{array}$ & $\begin{array}{l}-0.00 \\
(-0.12)\end{array}$ \\
\hline $\begin{array}{l}\text { Industry \& time } \\
\text { effects }\end{array}$ & Yes & Yes & Yes & Yes & Yes \\
\hline Observations & 5928 & 4411 & 1517 & 3993 & 1935 \\
\hline
\end{tabular}

Variable definitions: The dependent variable CEO_CH $=1$ if there is a change in the CEO in firm i during year t. SHR: annual shareholder returns; ROA: Return on assets; SALES: log of firm sales; MKT_BK: market value of the firm divided by the book value of assets; VOL: natural $\log$ of the standard deviation of stock returns over the year. STATE: dummy variable equal to one if the firm's ultimate owner is the Chinese State, and zero otherwise; LG1_OWN: Percentage share ownership of the largest shareholder; IND_DIR: the fraction of the board comprised of independent directors; BOARD_SIZE: Board size is measured as the number of individuals on the main board. COMBINE: leadership structure of the firm is a dummy variable set equal to one if the posts of CEO and chairman are combined, and zero otherwise; COMP_COMM: a dummy variable equal to one if the firm has a compensation committee and zero otherwise. The regressions contain a set of 13 industry variables and a set of 4 time dummies, from 2002 to 2005, with 2001 as the base year. Coefficients on the industry and time dummies are suppressed for expositional convenience. $* * * \mathrm{p}<0.01, * *$ $\mathrm{p}<0.05, * \mathrm{p}<0.1$. Standard errors are adjusted and clustered on the firm identifier. 
Table 8

Descriptive statistics: China and the US S\&P 1500 firms

Panel A: Executive compensation (median)

\begin{tabular}{lccccc}
\hline Year & China & $\begin{array}{c}\text { US } \\
\text { Cash pay }\end{array}$ & $\begin{array}{c}\text { Ratio } \\
\text { Col. }(2) \div(1)\end{array}$ & $\begin{array}{c}\text { US } \\
\text { Total pay }\end{array}$ & $\begin{array}{c}\text { Ratio } \\
\text { Col. }(4) \div(1)\end{array}$ \\
2001 & $\$ 33,565$ & $\$ 687,885$ & 20 & $\$ 1,915,779$ & 57 \\
2002 & $\$ 43,075$ & $\$ 758,806$ & 18 & $\$ 1,981,736$ & 46 \\
2003 & $\$ 56,775$ & $\$ 830,335$ & 15 & $\$ 1,990,033$ & 35 \\
2004 & $\$ 66,274$ & $\$ 907,517$ & 14 & $\$ 2,215,925$ & 33 \\
2005 & $\$ 48,329$ & $\$ 966,042$ & 20 & $\$ 2,323,643$ & 48 \\
Total & $\$ 49,775$ & $\$ 837,496$ & 17 & $\$ 2,094,315$ & 42 \\
\hline
\end{tabular}

Panel B: Firm and governance characteristics (median)

\begin{tabular}{lccc}
\hline Variable & China & US & P value of t test \\
SALES & 961.367 & $5,642.612$ & $0.000^{* * *}$ \\
SHR & -0.004 & 0.027 & $0.000^{* * *}$ \\
ROA & -0.160 & 0.166 & $0.000^{* * *}$ \\
MKT_BK & 1.570 & 1.330 & $0.000^{* * *}$ \\
BOARD_SIZE & 9.743 & 9.346 & $0.000^{* * *}$ \\
IND_RATIO & 0.269 & 0.693 & $0.000^{* * *}$ \\
COMBINE & 0.110 & 0.596 & $0.000^{* * *}$ \\
COMP_COMM & 0.368 & 0.981 & $0.000^{* * *}$ \\
\hline
\end{tabular}

Panel A: The Chinese compensation is translated from RMB to US \$ using average PPP exchange rates within the sample period. The PPP exchange rate is based on Penn World Table. 2001: 2.1153; 2002: 2.0894; 2003: 2.1142; 2004: 2.2062: 2005: 2.2281. The compensation data for U.S companies are calculated for S\&P1500 firms using the ExecuComp database. The compensation of the three highest paid executives is calculated as in the Chinese data.

Panel B: Median values reported in the table. SALES: firm sales (millions\$); SHR: annual shareholder returns; ROA: Return on assets; MKT_BK: market value of the firm divided by the book value of assets; IND DIR: the fraction of the board comprised of independent directors; BOARD SIZE: Board size is measured as the number of individuals on the main board. COMBINE: leadership structure of the firm is a dummy variable set equal to one if the posts of CEO and chairman are combined, and zero otherwise (average value reported); COMP_COMM: a dummy variable equal to one if the firm has a compensation committee and zero otherwise (average value reported). 
Table 9

Executive pay in China and the US: Pooled OLS results

\begin{tabular}{|c|c|c|c|c|c|}
\hline & $\begin{array}{l}(1) \\
\text { Pooled } \\
\text { Ln(PAY) } \\
\text { US= } \\
\text { salary+bonus }\end{array}$ & $\begin{array}{l}(2) \\
\text { Pooled } \\
\text { Ln(PAY) } \\
\text { US=total } \\
\text { pay }\end{array}$ & $\begin{array}{l}(3) \\
\text { USA } \\
\text { Ln(PAY) } \\
\text { US= } \\
\text { salary+bonus }\end{array}$ & $\begin{array}{l}(4) \\
\text { USA } \\
\text { Ln(PAY) } \\
\text { US=total } \\
\text { pay }\end{array}$ & $\begin{array}{l}(5) \\
\text { China } \\
\text { Ln(PAY) }\end{array}$ \\
\hline US & $\begin{array}{l}2.17 * * * \\
(79.64)\end{array}$ & $\begin{array}{l}2.80^{* * *} \\
(89.10)\end{array}$ & & & \\
\hline SHR & $\begin{array}{l}0.08^{* * *} \\
(4.35)\end{array}$ & $\begin{array}{l}-0.04^{*} \\
(-1.65)\end{array}$ & $\begin{array}{l}0.10^{* * *} \\
(4.27)\end{array}$ & $\begin{array}{l}-0.02 \\
(-0.99)\end{array}$ & $\begin{array}{l}0.13 * * * \\
(2.69)\end{array}$ \\
\hline ROA & $\begin{array}{l}0.13 * * \\
(1.97)\end{array}$ & $\begin{array}{l}0.11 \\
(1.30)\end{array}$ & $\begin{array}{l}-0.04 \\
(-0.26)\end{array}$ & $\begin{array}{l}-0.22 \\
(-1.53)\end{array}$ & $\begin{array}{l}0.19 * * * \\
(3.12)\end{array}$ \\
\hline SALES & $\begin{array}{l}0.28 * * * \\
(49.34)\end{array}$ & $\begin{array}{l}0.36^{* * *} \\
(50.10)\end{array}$ & $\begin{array}{l}0.32 * * * \\
(53.82)\end{array}$ & $\begin{array}{l}0.46^{* * *} \\
(63.28)\end{array}$ & $\begin{array}{l}0.25 * * * \\
(23.14)\end{array}$ \\
\hline MKT_BK & $\begin{array}{l}0.05^{* * *} \\
(7.73)\end{array}$ & $\begin{array}{l}0.11^{* * *} \\
(9.19)\end{array}$ & $\begin{array}{l}0.05^{* * *} \\
(7.92)\end{array}$ & $\begin{array}{l}0.15^{* * *} \\
(8.63)\end{array}$ & $\begin{array}{l}0.06^{* * *} \\
(3.97)\end{array}$ \\
\hline VOL & $\begin{array}{l}-0.04 * * \\
(-2.29)\end{array}$ & $\begin{array}{l}0.17 * * * \\
(8.82)\end{array}$ & $\begin{array}{l}0.04 * * \\
(2.35)\end{array}$ & $\begin{array}{l}0.39 * * * \\
(15.58)\end{array}$ & $\begin{array}{l}-0.06^{*} \\
(-1.77)\end{array}$ \\
\hline IND_DIR & $\begin{array}{l}0.23 * * * \\
(5.65)\end{array}$ & $\begin{array}{l}0.54 * * * \\
(10.57)\end{array}$ & $\begin{array}{l}-0.08^{* *} \\
(-2.16)\end{array}$ & $\begin{array}{l}0.13 * * \\
(2.23)\end{array}$ & $\begin{array}{l}0.59 * * * \\
(4.17)\end{array}$ \\
\hline BOARD_SIZE & $\begin{array}{l}0.01 * * * \\
(4.67)\end{array}$ & $\begin{array}{l}0.01 \text { *** } \\
(3.93)\end{array}$ & $\begin{array}{l}0.01 \text { *** } \\
(3.15)\end{array}$ & $\begin{array}{l}0.01 * \\
(1.77)\end{array}$ & $\begin{array}{l}0.01^{*} \\
(1.75)\end{array}$ \\
\hline COMPBINE & $\begin{array}{l}0.08 * * * \\
(5.87)\end{array}$ & $\begin{array}{l}0.07 * * * \\
(4.01)\end{array}$ & $\begin{array}{l}0.09 * * * \\
(7.22)\end{array}$ & $\begin{array}{l}0.10^{* * * *} \\
(5.34)\end{array}$ & $\begin{array}{l}0.10^{* * *} \\
(3.22)\end{array}$ \\
\hline COMP_COMM & $\begin{array}{l}0.14^{* * *} \\
(6.85)\end{array}$ & $\begin{array}{l}0.16^{* * *} \\
(7.89)\end{array}$ & $\begin{array}{l}0.06 \\
(0.96)\end{array}$ & $\begin{array}{l}0.15^{* *} \\
(2.00)\end{array}$ & $\begin{array}{l}0.12 * * * \\
(5.57)\end{array}$ \\
\hline Constant & $\begin{array}{l}1.89 * * * \\
(34.91)\end{array}$ & $\begin{array}{l}1.63^{* * *} \\
(20.64)\end{array}$ & $\begin{array}{l}3.99 * * * \\
(47.26)\end{array}$ & $\begin{array}{l}4.16^{* * * *} \\
(36.74)\end{array}$ & $\begin{array}{l}2.03 * * * \\
(13.53)\end{array}$ \\
\hline $\begin{array}{l}\text { Industry and } \\
\text { time effects }\end{array}$ & Yes & Yes & Yes & Yes & Yes \\
\hline Observations & 12552 & 12552 & 6629 & 6629 & 5928 \\
\hline R-squared & 0.85 & 0.88 & 0.57 & 0.51 & 0.27 \\
\hline
\end{tabular}

Variable definitions: The dependent variable $\ln (\mathrm{PAY})$ is the $\log$ of executive pay. The independent variables are: SALES: log of firm sales; SHR: annual shareholder returns; ROA: Return on assets; MKT BK: market value of the firm divided by the book value of assets; VOL: natural $\log$ of the standard deviation of stock returns over the year. IND DIR: the fraction of the board comprised of independent directors; BOARD_SIZE: Board size is measured as the number of individuals on the main board. COMBINE: leadership structure of the firm is a dummy variable set equal to one if the posts of CEO and chairman are combined, and zero otherwise; COMP_COMM: a dummy variable equal to one if the firm has a compensation committee and zero otherwise. The regressions contain a set of industry variables and a set of time dummies. Standard errors are adjusted and clustered on the firm identifier. 
Table 10

Panel A: Propensity Score Analysis: China-USA executive pay

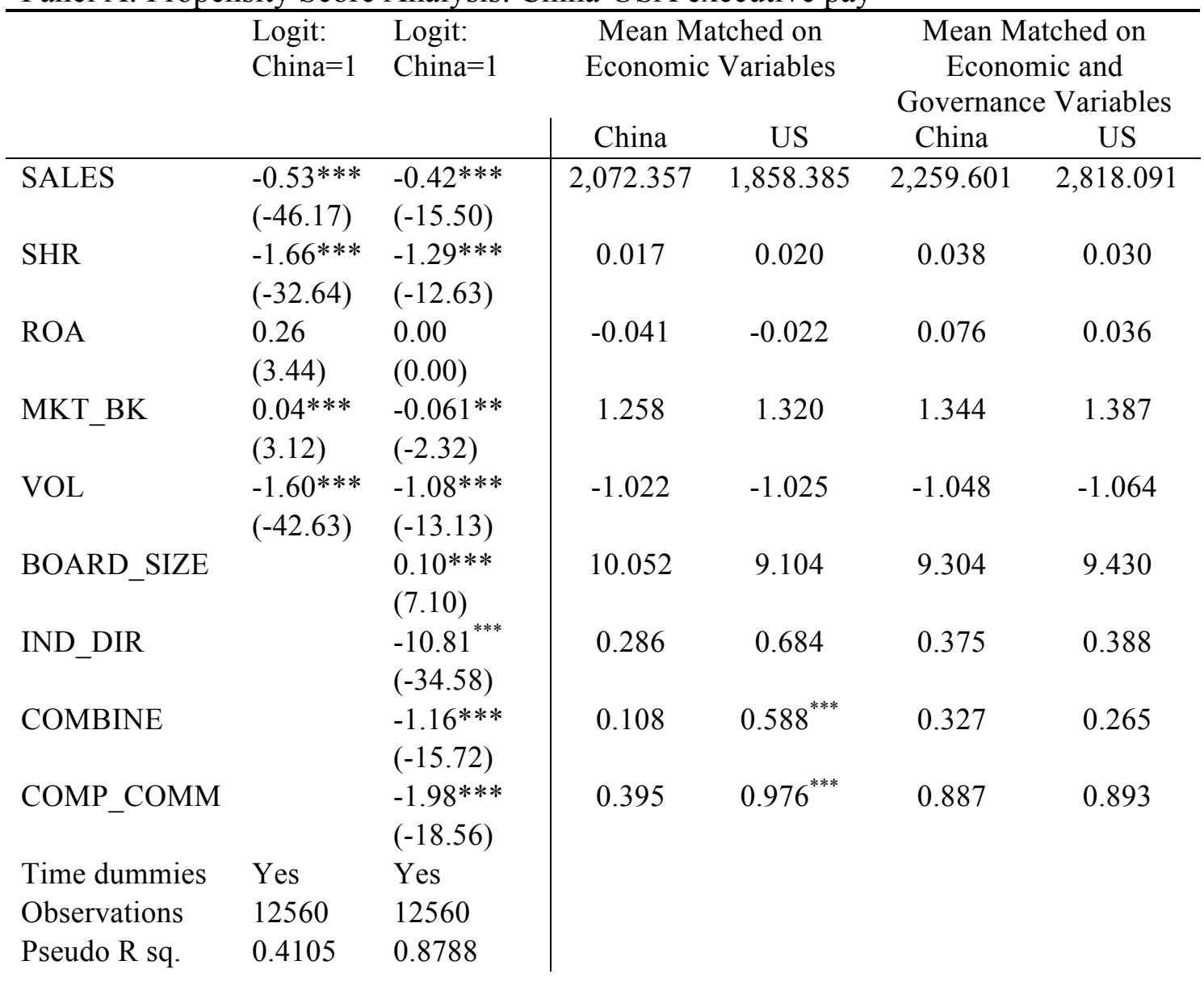

$* * *$ is statistically different from previous column

Panel B: Compensation difference between treatment Chinese firms and matched US firms

\begin{tabular}{|c|c|c|c|}
\hline & & $\begin{array}{c}\text { Matched on } \\
\text { Economic } \\
\text { Characteristics }\end{array}$ & $\begin{array}{c}\text { Matched on } \\
\text { Economic and } \\
\text { Governance } \\
\text { Characteristics }\end{array}$ \\
\hline \multicolumn{2}{|c|}{ Number of treatment firm-year observations } & 2211 & 309 \\
\hline \multicolumn{2}{|c|}{ Number of matched firm-year observations } & 2211 & 309 \\
\hline \multicolumn{2}{|c|}{ Mean of treatment $\log ($ comp. $)$} & 4.12 & 4.37 \\
\hline \multirow[t]{2}{*}{ Mean of matched } & Log (total comp.) & 7.31 & 7.27 \\
\hline & Log (salary+bonus) & 6.49 & 6.56 \\
\hline $\begin{array}{l}\mathrm{t} \text { test / } \\
\mathrm{p} \text { value }\end{array}$ & $\begin{array}{l}\log (\text { total comp. }) \\
\log (\text { salary+bonus })\end{array}$ & $\begin{array}{l}122.52 * * * \\
100.83^{* * *}\end{array}$ & $\begin{array}{l}41.75^{* * *} \\
35.67 * * *\end{array}$ \\
\hline \multicolumn{2}{|c|}{ Median of treatment $\log ($ comp. $)$} & 4.18 & 4.37 \\
\hline \multirow[t]{2}{*}{ Median of matched } & Log (total comp.) & 7.26 & 7.26 \\
\hline & Log (salary+bonus) & 6.46 & 6.46 \\
\hline \multirow{2}{*}{$\begin{array}{l}z \text { test } \\
p \text { value }\end{array}$} & Log (total comp.) & $57.20 * * *$ & $21.25^{* * *}$ \\
\hline & Log (salary+bonus) & $56.37 * * *$ & $20.78 * * *$ \\
\hline
\end{tabular}


Variable definitions: The dependent variable for the logit equation $=1$ if the country is China and 0 for the USA. The independent variables are: SALES: log of firm sales; SHR: annual shareholder returns; ROA: Return on assets; MKT_BK: market value of the firm divided by the book value of assets; VOL: natural log of the standard deviation of stock returns over the year. IND_DIR: the fraction of the board comprised of independent directors; BOARD_SIZE: Board size is measured as the number of individuals on the main board. COMBINE: leadership structure of the firm is a dummy variable set equal to one if the posts of CEO and chairman are combined, and zero otherwise; COMP_COMM: a dummy variable equal to one if the firm has a compensation committee and zero otherwise. Standard errors are adjusted and clustered on the firm identifier. $* * *$ significant at 0.01 level, $* *$ significant at 0.05 level, * significant at 0.10 level. 


\section{References}

Allen, Franklin, J. Qian, and M. J. Qian. 2005. Law, finance, and economic growth in China. Journal of Financial Economics 77 (1): 57-116.

Adithipyangkul, P., Alon I., And Zhang, T. (2010), "Executive Perks: Compensation and Corporate Performance in China", Asia Pacific Journal of Management, (forthcoming).

Baker, George P., and Brian J. Hall. 2004. CEO incentives and firm size. Journal of Labor Economics 22 (4): 767-798.

Brickley, James A., Jeffrey L. Coles, and Gregg Jarrell. 1997. Leadership structure: Separating the CEO and Chairman of the Board. Journal of Corporate Finance 3 (3): 189-220.

Chen, J.J., Liu, X., and Li, W. 2010. The Effect of Insider Control and Global Benchmarks on Chinese Executive Compensation. Corporate Governance: An International Review, 18(2): pp107-123.

Chen, Jing, Mahmoud Ezzamel, and Ziming Cai 2010. Managerial power, tournament theory and executive pay in China, Working paper Managerial Compensation conference, Cardiff, (September)

Chen, Zhihong, Guan, Yuyan and Ke, Bin, 2010. Does Managerial Stock Option Compensation Increase Shareholder Value in State-Controlled Chinese Firms Listed in Hong Kong? (April 19, 2010). Available at SSRN: http://ssrn.com/abstract $=1249526$

Chinese Security Law (1999) Rule number 16 of Chinese Security Law of 1999

CSRC. 1998. Guidelines on contents and formats of information disclosure of annual report for listed companies_-1998 version. People's Republic of China: China Securities Regulatory Commission.

CSRC. 2000. Guidelines on contents and formats of information disclosure of annual report for listed companies_-2000 version. People's Republic of China: China Securities Regulatory Commission.

CSRC. 2001. Guidelines for introducing independent directors to the board of directors of listed companies. People's Republic of China: China Securities Regulatory Commission.

CSRC. 2002. Code of corporate governance for listed companies in China. People's Republic of China: China Securities Regulatory Commission.

CSRC. 2002. Guidelines on contents and formats of information disclosure of annual report for listed companies_-2002 version. People's Republic of China: China Securities Regulatory Commission.

CSRC. 2005. Regulation for the Stock Options Grants in Public Firms.

CSRC. 2005. Guidelines on contents and formats of information disclosure of annual report for listed companies-2005 version. People's Republic of China: China Securities Regulatory Commission.

Coughlan, Anne T., and Ronald M. Schmidt, 1985, Executive Compensation, Management Turnover and Firm Performance: An Empirical Investigation, Journal of Accounting \& Economics 7, 43-66.

Conyon, Martin J., and He Lerong. 2004. Compensation Committees and CEO Compensation Incentives in U.S. Entrepreneurial Firms. Journal of Management Accounting Research 16: 35-56. 
Conyon, Martin J., and Kevin J. Murphy. 2000. The Prince and the Pauper? CEO Pay in the United States and United Kingdom. The Economic Journal 110 (467): F640-F671.

Conyon, Martin J., Nuno Fernandes, Miguel A. Ferreira, Pedro Matos, and Kevin J. Murphy, 2010, The Executive Compensation Controversy: A Transatlantic Analysis, presented by Kevin Murphy at Productivity, Profits and Pay Conference organized by Fondazione Rodolfo Debenedetti http://www.frdb.org/scheda.php?id=8\&doc_pk=11042.

Conyon, Martin J., and Simon I. Peck. 1998. Board control, remuneration committees, and top management compensation. Academy of Management Journal 41 (2): 146-157.

Conyon, Martin J., and Core, John E., and Wayne R. Guay. 2010. Are US CEOs paid more than UK CEOs? Inferences from risk adjusted pay. Review of Financial Studies

Core, John E., and Wayne R. Guay. 2010. Is CEO pay too high and incentives too low? A wealth-based contracting framework. Academy of Management Perspectives 24 (1): In Press.

Core, John E., and Wayne R. Guay. 1999. The use of equity grants to manage optimal equity incentive levels. Journal of Accounting \& Economics 28 (2): 151-184.

Core, John E., Wayne R. Guay, and David F. Larcker. 2003. Executive equity compensation and incentives: A survey. FRBNY Economic Policy Review: 2744.

Core, John E., Robert W. Holthausen, and David F. Larcker. 1999. Corporate governance, chief executive officer compensation, and firm performance. Journal of Financial Economics 51 (3): 371-406.

DeFond, M. L., T. J. Wong, and S. H. Li. 1999. The impact of improved auditor independence on audit market concentration in China. Journal of Accounting \& Economics 28 (3): 269-305.

Demsetz, Harold, and Kenneth Lehn. 1985. The structure of corporate-ownership causes and consequences. Journal of Political Economy 93 (6): 1155-1177.

Ding, S., Zhenyu Wu, Yuanshun Li and Chunxin Jia (2010) Executive compensation, supervisory board, and China's governance reform: a legal approach perspective, Review of Quantitative Finance and Accounting (2010) 35:445471.

Ding, Y. H. Zhang, and J. Zhang. 2007. Private vs state ownership and earnings management. Corporate Governance: an International Review, 15 (2): 223238.

Fama, Eugene F., and Michael C. Jensen. 1983a. Agency Problems and Residual Claims. Journal of Law and Economics 26 (2): 327-349. . 1983b. Separation of Ownership and Control. Journal of Law and Economics 26 (2): 301-325.

Fan, Joseph. P. H., T. J. Wong, and T. Y. Zhang. 2007. Politically connected CEOs, corporate governance, and Post-IPO performance of China's newly partially privatized firms. Journal of Financial Economics 84 (2): 330-357.

Fan, Joseph. P. Jun Huang, Felix Oberholzer-Gee, and Mengxin Zhao. 2009. Bureaucrats as Managers - Evidence from China. Working paper, Harvard Business School.

Firth, Michael, Peter M. Y. Fung, and Oliver M. Rui. 2007. How ownership and corporate governance influence chief executive pay in China's listed firms. Journal of Business Research 60 (7): 776-785. 
Firth, M., Fung, P. M. Y., Rui, O. M. 2006, Corporate performance and CEO compensation in China. Journal of Corporate Finance, 12, 693-714.

Frank, R.H. and Cook, P.J. (1995). Winner-Take-All Society. New York, Free Press.

Graham, John R., Li, Si and Qiu, Jiaping (2010), Managerial Attributes and Executive Compensation (September 14, 2009). AFA 2010 Atlanta Meetings Paper. Available at SSRN: http://ssrn.com/abstract $=1266680$

Hall, Brian J., and Jeffrey B. Liebman. 1998. Are CEOs really paid like bureaucrats? Quarterly Journal of Economics 113 (3): 653-691.

Heckman, James J., Hidehiko Ichimura, and Petra Todd. 1997. "Matching as an Econometric Evaluation Estimator: Evidence from a Job Training Programme." Review of Economic Studies, 64:4, 605 - 654.

Heckman, James J., Hidehiko Ichimura, and Petra Todd. 1998. Matching as an Econometric Evaluation Estimator." Review of Economic Studies, 65:2 , 261294.

Hermalin, Benjamin E., and Michael S. Weisbach. 1998. Endogenously chosen boards of directors and their monitoring of the CEO. American Economic Review 88 (1): 96-118.

- 2003. Boards of directors as an endogenously determined institution: A survey of the economic literature. Economic Policy Review

Holmstrom, Bengt. 1979. Moral hazard and observability. Bell Journal of Economics 10 (1): 74-91.

Hu, Helen Wei \& On Kit Tam \& Monica Guo-Sze Tan (2010) Internal governance mechanisms and firm performance in China, Asia Pacific Journal of Management, 27:727-749

Jensen, Michael C. 1993. The Modern Industrial Revolution, Exit, and the Failure of Internal Control Systems. The Journal of Finance 48 (3): 831-880.

Jensen, Michael C., and William H. Meckling. 1976. Theory Of Firm - Managerial Behavior, Agency Costs And Ownership Structure. Journal of Financial Economics 3 (4): 305-360.

Jensen, Michael C., and Kevin J. Murphy. 1990. Performance Pay and TopManagement Incentives. The Journal of Political Economy 98 (2): 225-264.

Jensen, Michael C., and J. B. Warner. 1988. The distribution of power among corporate managers, shareholders, and directors. Journal of Financial Economics 20 (1-2): 3-24.

Jingu, Takeshi. 2007. Corporate Governance for Listed Companies in China - Recent Moves to Improve the Quality of Listed Companies. Nomura Capital Market Review, Vol. 10, No. 2 http://ssrn.com/paper $=1016912$

Kaplan, S and Minton B. 2006. How has CEO Turnover Changed? Increasingly Performance Sensitive Boards and Increasingly Uneasy CEOs. NBER Working Paper No. 12465

Kato, Takao K., and Cheryl X. Long. 2006a. CEO turnover, firm performance, and enterprise reform in China: Evidence from micro data. Journal of Comparative Economics 34 (4): 796-817.

2006b. Executive compensation, firm performance, and corporate governance in China: Evidence from firms listed in the Shanghai and Shenzhen Stock Exchanges. Economic Development and Cultural Change 54 (4): 945-983.

2006c. Executive turnover and firm performance in China. American Economic Review 96 (2): 363-367. 
Ke, B., O. Rui, and W. Yu. 2009. Hong Kong stock listing and the sensitivity of managerial compensation to firm performance in state-controlled Chinese firms. Working paper. Pennsylvania State University.

La Porta, R., Lopez-de-Silanes F., Shleifer, A., and Vishny, R. 1998. Law and finance. Journal of political Economy 106 (6): 1113.

La Porta, R., Lopez-de-Silanes F., Shleifer, A., and Vishny, R. 2000. Investor protection and corporate governance. Journal of Financial Economics 58 (1/2): 3-27.

Leuven, Edwin, and Barbara Sianesi. 2003. PSMATCH2: Stata Module to Perform Full Mahalanobis and Propensity Score Matching, Common Support Graphing, and Covariate Imbalance testing, Version 3.1.5. May 2, 2009. Available at ://ideas.repec.org/c/boc/bocode/s432001.html.

Magnan, M. and A. T. Li. 2008. Equity-based compensation: an important determinant for Chinese cross listed firms. Available at SSRN: http://ssrn.com/abstract $=1082888$

Mengistae, T., and L. X. C. Xu. 2004. Agency theory and executive compensation: The case of Chinese state-owned enterprises. Journal of Labor Economics 22 (3): $615-637$.

Mirrlees, James A. 1976. Optimal structure of incentives and authority within an organization. Bell Journal of Economics 7 (1): 105-131. . 1997. Information and incentives: The economics of carrots and sticks. Economic Journal 107 (444): 1311-1329.

Murphy, Kevin J., and Tatiana Sandino. 2009. Executive Pay and 'Independent' Compensation Consultants. Available at http://ssrn.com/abstract=1148991; Journal of Accounting and Economics (in Press)

Murphy, Kevin J. 1985. Corporate performance and managerial remuneration - an empirical-analysis. Journal of Accounting \& Economics 7 (1-3): 11-42. . 1996. Reporting Choice and the 1992 Proxy Disclosure Rules. Journal of Accounting, Auditing \& Finance 11 (3): 497-515. . 1999. Executive compensation. Handbook of Labor Economics, vol. 3 b B2 Handbook of Labor Economics, vol. 3b: 2485-2563.

Newman, H. A., and H. A. Mozes. 1999. Does the composition of the compensation committee influence CEO compensation practices? Financial Management 28 (3): 41

Qian, Y. 1995. Reforming corporate governance and finance in China. Corporate governance in transitional economies-insider control and the role of banks, The World Bank, 215-252.

Rosenbaum, Paul R., and Donald B. Rubin. 1983. "The Central Role of the Propensity Score in Observational Studies for Causal Effects. Biometrika 70:1, 41-55.

Rubin, Donald B. 2006. Matched Sampling for Causal Effects: Cambridge: Cambridge University Press.

Rosen, S. 1981. "The economics of superstars." American Economic Review, 71(5) 845-858.

Schaefer, Scott. 1998. The dependence of pay-performance sensitivity on the size of the firm. Review of Economics and Statistics 80 (3): 436-443.

Shivdasani, A. 1993. Board composition, ownership structure, and hostile takeovers. Journal of Accounting \& Economics 16 (1-3): 167-198.

Smith, Clifford W., and Ross L. Watts. 1992. The investment opportunity set and corporate financing, dividend, and compensation policies. Journal of Financial Economics 32 (3): 263-292. 
Weisbach, M. 1988. "Outside Directors and CEO Turnover." Journal of Financial Economics 20: 431-60.

White, Halbert. 1980. A heteroskedasticity-consistent covariance matrix estimator and a direct test for heteroskedasticity. Econometrica 48: 431-460.

Wooldridge, J. M., 2002, Econometric Analysis of Cross Section and Panel Data, The MIT Press

Xi, Chao. 2006. In search of effective monitoring board model: Board reforms and the political economy of Corporate Law in China. Connecticut Journal of International Law 22 (1): 1-46.

$\mathrm{Xu}$, Liping, 2004 Types of large shareholders, corporate governance, and firm performance : evidence from China's listed companies, Ph.D., School of Accounting and Finance, The Hong Kong Polytechnic University, 2004

Yermack, David. 1996. Higher market valuation of companies with a small board of directors. Journal of Financial Economics 40 (2): 185-211.

Yoshikawa, T. and Rasheed, A. (2009), "Convergence of corporate governance: Critical review and future directions," Corporate Governance: An International Review, 17(3), 388-404. 